\title{
IRRIGATION MANAGEMENT OF POTATOES USING SENSOR FEEDBACK: TEXAS HIGH PLAINS
}

\author{
S. A. O'Shaughnessy, M. A. Andrade, P. D. Colaizzi, \\ F. Workneh, C. M. Rush, S. R. Evett, M. Kim
}

Beyond 2020,

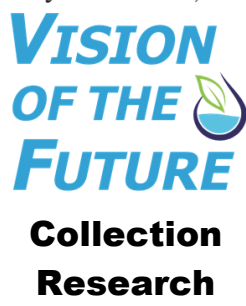

\section{Highlights}

- Potatoes irrigated at $80 \%$ and $100 \%$ replenishment of soil water depletion to field capacity resulted in statistically similar tuber yields and irrigation water productivity.

- In the drier growing season, irrigation scheduling using sensor feedback resulted in fewer irrigations compared with the manual-control method.

- In the wetter growing season, irrigation scheduling using sensor feedback resulted in similar or better tuber yields compared with the manual-control method.

ABSTRACT. Few studies have investigated yield and crop water productivity of plant and soil water sensing feedback systems for site-specific irrigation management of a potato crop. In this two-year study (2018 and 2019), the irrigation scheduling supervisory control and data acquisition (ISSCADA) system developed by scientists at the USDA-ARS Conservation and Production Research Laboratory in Bushland, Texas, was used to manage a potato crop at three irrigation levels. The ISSCADA system used two different irrigation scheduling methods: (1) plant feedback and (2) a hybrid method that combines plant feedback with soil water sensing with a soil water depletion (SWD) threshold initially set at 50\% and reduced to $35 \%$ in the second year. Tuber yield, crop water productivity (CWP), and irrigation water productivity (IWP) resulting from the two ISSCADA irrigation scheduling methods were compared with a manual-control method based on weekly neutron probe readings. The irrigation levels were $100 \%, 80 \%$, and $60 \%\left(I_{100}, I_{80}\right.$, and $\left.I_{60}\right)$ of full and were accomplished by either replenishment of SWD to field capacity or by the equivalent plant feedback or SWD thresholds of the ISSCADA system. In the second study year, the SWD threshold was reduced to 35\%. Cumulative irrigation amounts for the ISSCADA treatment methods were significantly less compared with the manual-control method in the $I_{100}$ levels for both years. This resulted in significantly smaller tuber yields and CWP in the first year of the study, a hot dry growing season. In the second year of the study, tuber yields and CWP were similar between irrigation scheduling methods, and IWP was significantly greater for the ISSCADA-plant feedback method. Considering the effect of irrigation treatment, the tuber yields, CWP, and IWP between the $I_{100}$ and $I_{80}$ levels were similar in both years, resulting in an average savings of $85 \mathrm{~mm}$ at the $I_{80}$ level. Future studies are needed to investigate if the change in the SWD threshold could enable the ISSCADA-hybrid system to adjust to variable climatic conditions and successfully irrigate potatoes in this region.

Keywords. Center pivot, Dynamic prescription maps, Plant The authors have paid for open access for this article. This work is licensed under a Creative Commons AttributionNonCommercial-NoDerivatives 4.0 International License https://creative commons.org/licenses/by-nc-nd/4.0/

Submitted for review in January 2020 as manuscript number NRES 13925; approved for publication as a Research Article and as part of the National Irrigation Symposium 2020 Collection by the Natural Resources \& Environmental Systems Community of ASABE in April 2020.

Mention of company or trade names is for description only and does not imply endorsement by the USDA. The USDA is an equal opportunity provider and employer.

The authors are Susan A. O'Shaughnessy, Research Agricultural Engineer, USDA-ARS Conservation and Production Research Laboratory, Bushland, Texas; Manuel A. Andrade, Assistant Professor, Department of Agriculture, Veterinary, and Rangeland Sciences, University of Nevada, Reno, Nevada; Paul D. Colaizzi, Research Agricultural Engineer, USDAARS Conservation and Production Research Laboratory, Bushland, Texas; Fekede Workneh, Senior Research Scientist, and Charles M. Rush, Professor of Plant Pathologist, Texas A\&M AgriLife Research, Amarillo, Texas; Steven R. Evett, Research Soil Scientist, USDA-ARS Conservation and Production Research Laboratory, Bushland, Texas; Minyoung Kim, Agricultural Engineer, National Institute of Agricultural Sciences, Rural Development Administration, Jeonju, South Korea. Corresponding author: Susan O'Shaughnessy, 2300 Experiment Station Road, Bushland, TX 79012; phone: 806-356-5770; e-mail: susan.oshaughnessy@usda.gov. feedback, Site-specific variable-rate irrigation, Soil water sensing feedback, Wireless sensor networks.

$\mathrm{T}$ The Texas High Plains is known for its production of grain crops for cattle feed; however, with low grain commodity prices, many producers are looking for ways to diversify their production systems. Potato (Solanum tuberosum L.) is a higher-value crop, and the majority of potatoes that are grown in this region are chipping potatoes cultivated in well drained loamy soils (USDANRCS, 2020) located in the northwestern counties of the Texas Panhandle. Other major regions in the state that produce potatoes are located in the Lower Rio Grande Valley and in the South Texas Brush Country area. The crop requires a moderate amount of water (500 to $750 \mathrm{~mm}$ ) (Enciso et al., 2009), and its yield is sensitive to stress from water deficit, but the crop is also susceptible to yield reduction, 
disease, and rot from water ponding due to soil saturation (Yost et al., 2019). Many field studies of potato crops under deficit irrigation were performed in coarse soils. One study concerning potato production in clay loam soils in the Southern High Plains, published by Box et al. (1963), reported that tuber yield increased with soil water, but tubers in the highest irrigated plots were also negatively affected by maximum daily air temperatures exceeding $21.7^{\circ} \mathrm{C}$. Under- and overirrigation of a potato crop in the Pullman clay loam soils common to much of the Texas Panhandle is of particular concern because of the high clay content, where too little irrigation could reduce yields and alter the shape of the tubers (Robins and Domingo, 1956; Ruf, 1964; Sanders et al., 1972), while over-irrigation could expose potatoes to disease or cause rotting (Adams and Stevenson, 1990; Olanya et al., 2010). Pullman soils represent $30 \%$ of the Texas High Plains $\left(\sim 20,000 \mathrm{~km}^{2}\right)$ (USDA-NRCS, 1995).

It is possible that sensor feedback can be used to optimize irrigation scheduling for potatoes. El-Abedin et al. (2017) used down-hole capacitive sensors (EnviroSCAN, Sentek Sensor Technologies, Tucson, Ariz.) on potatoes irrigated to replace $100 \%, 70 \%$, or $50 \%$ of evapotranspiration (ET). Although they did not schedule irrigations based on soil water sensing data, they were able to monitor fluxes and differences in soil water levels among the different irrigation regimes. In a semiarid region in Lebanon, Karam et al. (2014) studied potato production under different levels of subsurface drip irrigation. Soil water content was sensed using a frequency domain reflectometer (Sentry 200-AP, Troxler Electronic Laboratories, Durham, N.C.) to replenish soil water deficit in the upper $60 \mathrm{~cm}$ of the soil profile. Full replenishment of soil water depletion to field capacity resulted in tuber yields that averaged $62.5 \mathrm{t} \mathrm{ha}^{-1}$.

Rather than use soil water sensing to monitor water stress, Rud et al. (2014) used direct measurements of stomatal conductance (SC) to identify the variability of plant-available water in a potato field. They determined that a theoretical crop water stress index (CWSI) correlated well with SC readings and concluded that the theoretical CWSI was stable enough to be used to schedule irrigations. Gerhards et al. (2016) used hyperspectral and thermal imaging to detect water stress in potatoes. They determined that temperaturebased indices responded sooner than spectral indices (NDVI) and that the CWSI was suitable for water stress detection. Shae et al. (1999) used an empirical CWSI to apply surface drip irrigation to potatoes. They compared yields and crop water productivity (CWP) produced from irrigations scheduled with the CWSI to those from treatment plots using three different irrigation scheduling methods, i.e., an algorithm to estimate soil water depletion, a crop model (SUBSTOR-Potatoes), and tensiometer readings. They determined early on that the CWSI method of irrigation (plant feedback) required supplemental soil water readings from tensiometers because of high CWSI readings due to incomplete canopy cover and high relative humidity and low CWSI readings from cloud cover and low air temperature. With the combined feedback (plant and soil water sensing), they reported that yields and CWP were similar among the three irrigation scheduling methods. King et al. (2006) used time domain reflectometers (TDR) (CS615, Campbell Scientific, Logan, Utah) to determine the average soil water content in a management zone and a site-specific decision support irrigation model to maintain plant-available water in the root zone at $65 \%$. They compared potato yields from sitespecific variable-rate irrigation (SS-VRI) with conventional uniform irrigation. Although tuber yields trended greater for the SS-VRI scheduling method for both years in the twoyear study, yields were not significantly different. The authors concluded that soil water measurements alone may not be the optimal parameter to use in decision support for SSVRI. However, the CS615 sensor and its later version the CS616 have been found to lack accuracy (Chávez and Evett, 2012; Evett and Parkin, 2005) and that may have negatively influenced the results of King et al. (2006). Using a more accurate soil water sensor could result in a better outcome.

The irrigation scheduling supervisory control and data acquisition (ISSCADA) system developed and patented at Bushland, Texas (Evett et al., 2014) has been used to automatically manage site-specific scheduling of center-pivot irrigation for grain crops (O'Shaughnessy et al., 2017) and cotton (O'Shaughnessy et al., 2015). Grain and lint yields produced in the highest irrigated treatment plots managed by the ISSCADA system in those studies were similar or better compared with a manual-control method of irrigation scheduling using weekly neutron probe readings. In those earlier studies, the ISSCADA system used canopy temperature from a network of wireless infrared thermometers (IRTs) and weather data to calculate an integrated crop water stress index (iCWSI) for daylight hours from $2 \mathrm{~h}$ after sunrise to $2 \mathrm{~h}$ before sunset, which was then used to signal irrigations. The iCWSI was intended to reduce the weather-induced variability of CWSI values obtained from one-time-of-day canopy temperature readings. Soil water sensing was recently incorporated into the ISSCADA system to ensure closedloop feedback to prevent over- and under-irrigation, especially in sub-humid and humid regions where the ISSCADA system was recently deployed (O'Shaughnessy et al., 2018; Stone et al., 2019; Vories et al., 2019). Software developed by USDA-ARS (Andrade et al., 2015) integrated the sensor network systems with commercial VRI hardware to build dynamic prescription maps and control irrigations. The benefits of an ISSCADA system are that it can simplify the complexity of using sensor feedback to manage VRI systems by automatically collecting the data, applying scheduling algorithms, and providing decision support for crop water management in the form of prescription maps (Andrade et al., 2017). The ISSCADA system had not been tested on potatoes. Our hypothesis was that the ISSCADA-plant feedback irrigation scheduling method would produce tuber yields similar to those of the manual-control method at the full irrigation level, similar to the results reported by O'Shaughnessy et al. (2015). Moreover, we hypothesized that the ISSCADA-hybrid irrigation scheduling method using a combination of soil water sensing with plant feedback would help optimize irrigation management of potatoes irrigated at full and deficit levels. This hypothesis is supported by findings reported by Shae et al. (1999) when using soil water sensing with plant feedback for irrigation scheduling of potatoes and following the recommendation from King et al. 
(2006) to use combined sensing systems for irrigation management of potatoes but using more accurate water sensing based on TDR principles.

The main objective of this study was to compare potato production based on the following irrigation scheduling methods: (1) manual control (designated M) using weekly neutron probe readings, (2) the ISSCADA-plant feedback method (designated $\mathrm{C}$ ), and (3) the ISSCADA-hybrid method (designated $\mathrm{H}$ ), which combine soil water sensing with plant feedback. The performance of the three irrigation scheduling methods was determined by comparing tuber yields, seasonal crop water use $\left(\mathrm{ET}_{c}\right)$, crop water productivity (CWP), and irrigation water productivity (IWP) based on main treatment effects of irrigation scheduling method and irrigation level. A secondary objective was to compare the effect of three irrigation treatment levels $(100 \%, 80 \%$, and $60 \%$ replenishment of soil water depletion to field capacity, designated $\mathrm{I}_{100}, \mathrm{I}_{80}$, and $\mathrm{I}_{60}$, respectively) on potato production in Pullman clay loam soils. A tertiary objective was to examine the efficacy of iCWSI thresholds that were developed based on literature values of CWSI for well- and deficit-irrigated conditions.

\section{Materials AND Methods}

A mid-season chipping potato crop, variety FL 1867, was planted on 5-7 April 2018 and 3-5 April 2019 under one-half of a three-span VRI center-pivot field (fig. 1). Potato seeds were planted 0.17 to $0.30 \mathrm{~cm}$ apart to a depth of $0.20 \mathrm{~m}$ in 12-row plots. The beds were spaced $0.76 \mathrm{~m}$ apart using a

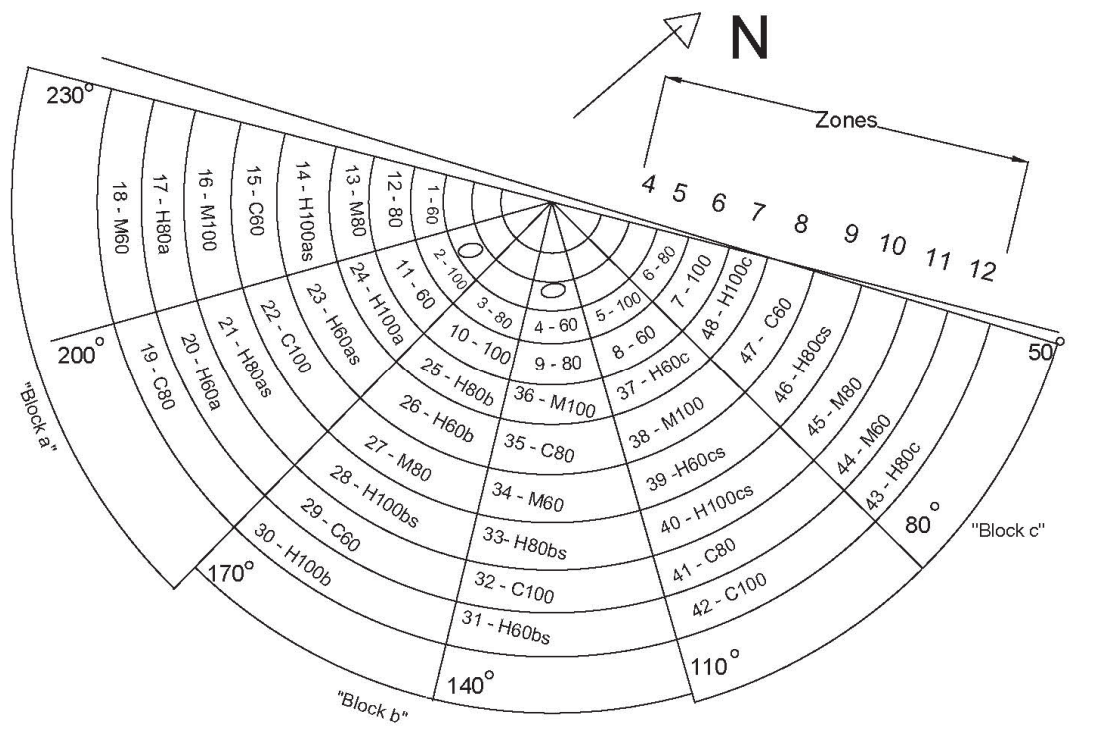

IRTs- well-watered location

\begin{tabular}{|l|l|}
\hline \multicolumn{2}{|c|}{ North Pivot- 2018} \\
\hline Irrigation Scheduling Methods \\
\hline $\mathrm{M}$ & Weekly neutron probe \\
\hline $\mathrm{H}$ & $\begin{array}{l}\text { Hybrid - Soil water* } \\
\text { \& plant feedback }\end{array}$ \\
\hline $\mathrm{C}$ & Plant feedback \\
\hline Irrigation Treatment Levels \\
\hline $100,80,60 \%$ replenishment of field capacity \\
\hline $\begin{array}{r}\text { Zones } 5 \text { \& } 6 \text { psyllid inoculations } \\
\text { (plots 1-12) }\end{array}$ \\
\hline
\end{tabular}

*s designates location of soil wate sensing station.

Each plot will have a neutron access tube

(a) 2018 growing season

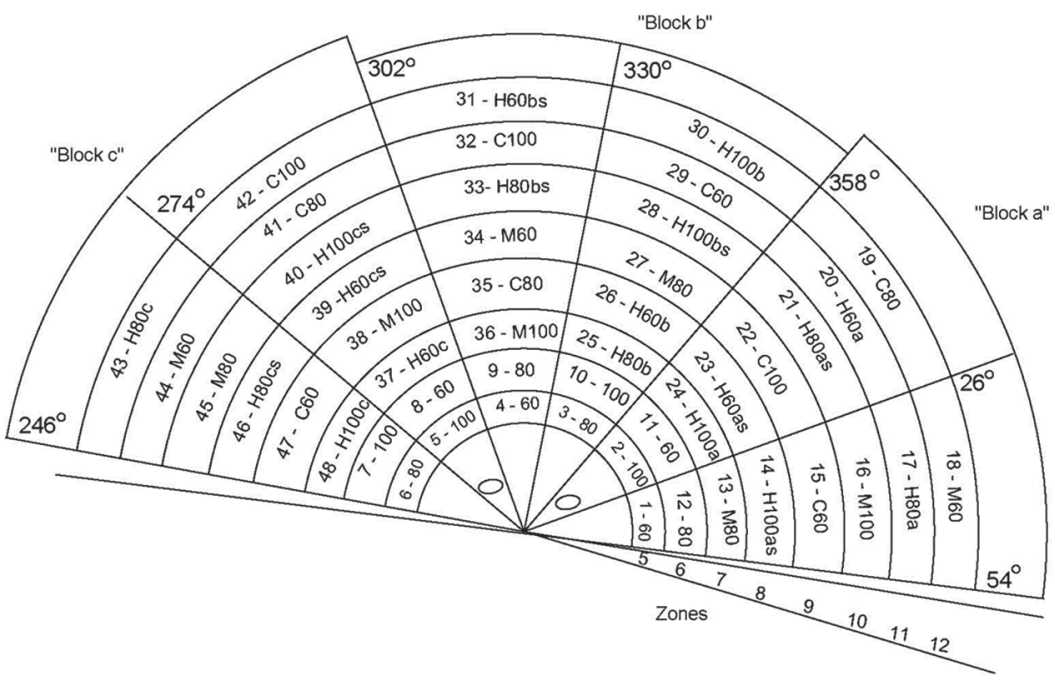

IRTs- well-watered location

\begin{tabular}{|l|l|}
\hline \multicolumn{2}{|c|}{ North Pivot- 2019} \\
\hline Irrigation Scheduling Methods \\
\hline $\mathrm{M}$ & Weekly neutron probe \\
\hline $\mathrm{H}$ & $\begin{array}{l}\text { Hybrid - Soil water } \\
\text { \& plant feedback }\end{array}$ \\
\hline $\mathrm{C}$ & Plant feedback \\
\hline Irrigation Treatment Levels \\
\hline $100,80,60 \%$ replenishment of full \\
\hline $\begin{array}{l}\text { Zones } 5 \text { \& } 6 \text { psyllid infestation } \\
\text { (plots 1-12) }\end{array}$ \\
\hline \multirow{2}{*}{$\begin{array}{c}\text { *s designates location of soil water } \\
\text { sensing station. }\end{array}$} \\
$\begin{array}{l}\text { Each plot will have a neutron } \\
\text { access tube. }\end{array}$
\end{tabular}

(b) 2019 growing season

Figure 1. Experimental plot plan for potato field at Bushland, Texas, for the (a) 2018 and (b) 2019 growing seasons. Sectors were blocked (a, b, c) to help address any field variability. Irrigation scheduling methods were: $\mathbf{H}=$ hybrid, $\mathrm{C}=$ plant feedback, and $\mathbf{M}=$ manual control. Irrigation levels were $100 \%, 80 \%$, and $60 \%$ replenishment of soil water depletion to field capacity in the top $1.5 \mathrm{~m}$. The letter "s" indicates the location of a soil water sensing station. 
GPS-guided tractor. For this study, the cropped half of the field was divided into 36 management zones (MZs) (plots 13 to 48 ), while plots 1 to 12 were part of a separate study. Plots were blocked into three $60^{\circ}$ sectors (designated blocks a, b, and c), and irrigation scheduling methods and irrigation levels were randomized within each block (figs. 1a and 1b). A neutron access tube (rigid, thin-wall, galvanized-steel conduit, $0.038 \mathrm{~m} \mathrm{ID} \times 2.4 \mathrm{~m}$ length) was installed in the center of each treatment plot. Soil water content readings with the neutron probe were taken once the access tubes were installed and the day after harvest in all treatment plots, every $30 \mathrm{~d}$ in deficit-irrigated plots, and weekly in the highest irrigated plots managed using the manual scheduling method.

\section{Agronomic and Farming Practices}

Soil samples were taken in early spring of both years to a depth of $20 \mathrm{~cm}$ and analyzed by a third-party company to determine fertilizer rates to meet a tuber yield goal of $39 \mathrm{Mg}$ $\mathrm{ha}^{-1}$. Sweeps were used to plow the fields, a six-row disc bedder was used to establish semi-circular beds in the semicircle portion of the field to be planted, and a culti-packer was used to firm up the beds just prior to planting. Fertilizer at the rates recommended to meet target yield was applied prior to planting. S-metolachlor (Brawl II, Tenkōz, Inc., Alpharetta, Ga.) was applied as a pre-emergent herbicide following planting in 2018 (table 1).

In 2019, a different combination of herbicides was used (table 1) due to weed pressure experienced from pig weed (Amaranthus retroflexus) in the previous year. Furrows were not diked to help maintain the chemical barrier at the soil surface. The second dose of $\mathrm{N}$ was not applied due to the unavailability of chemigation equipment. However, Rens et al. (2015) reported that application of $\mathrm{N}$ at tuber initiation did not improve marketable potato yield or tuber quality for the FL1867 variety that had received adequate $\mathrm{N}$ at preplant. A pesticide (Brigade EC, FMC Corp., Philadelphia, Pa.) was applied in early July to control black blister beetles that infested the outer three plant rows, causing marked defoliation in this buffer area, which was planted to prevent edge effects. In both years, biophysical measurements of plant height and width were completed bi-weekly until plant height reached its pinnacle and canopy cover was nearly $100 \%$. Destructive plant samples were taken in each of the $\mathrm{M}_{100}, \mathrm{M}_{80}$, and $\mathrm{M}_{60}$ treatment plots on a bi-weekly basis to determine tuber growth stage and mass.

Decision support (irrigation timing and amount) in the form of a dynamic prescription map was computed automatically at midnight, after the ISSCADA system traveled across the field. A more detailed description of the
ISSCADA system is provided below and by Andrade et al. (2015, 2016, 2017).

\section{VRI SPRINKLER DESIGN}

The center-pivot irrigation system was a three-span Valley 8000 model equipped with a commercial Valley VRI zone control system (Valmont Industries, Valley, Neb.) in which a hydraulic valve was plumbed into each drop hose. Six hydraulic valves were daisy chained to each other, creating a control zone of six drops, and valve operation was controlled by an electronic solenoid housed inside each VRI tower box. A GPS receiver was located at the end tower and transmitted data using power line carrier communication over the $120 \mathrm{VAC}$ line to the control panel. The drop hoses were spaced $1.5 \mathrm{~m}$ apart, with drops located in every other furrow, resulting in control zones of $9 \mathrm{~m}$ radial width. The application method was low-elevation spray application (LESA) with low-drift nozzle (LDN) and pad assemblies located approximately $0.46 \mathrm{~m}$ above the ground. A more detailed description of the VRI sprinkler system and its performance was provided by O'Shaughnessy et al. (2013).

\section{CORE HARDWARE OF ISSCADA SYSTEM}

The core components of the ISSCADA system were outfitted onto the VRI center-pivot sprinkler with a Pro2 control panel, including an embedded computer (MXE-1401, Adlink, Irvine, Cal.) located at the pivot point. This computer received data from wireless sensor networks (WSNs) of IRTS (SAP-IP IRTs, Dynamax, Inc., Houston, Tex.), a weather station (Campbell Scientific), and soil water sensors (TDR-315L, Acclima, Inc., Meridian, Ida.). Data from the IRTs were collected at the embedded computer using an SAP-IP coordinator (Dynamax, Inc.); the communication protocol was Zigbee (IEEE 802.15.4, bandwidth of $2.4 \mathrm{GHz}$ ). A spread-spectrum radio (RF401a, Campbell Scientific), configured as a base-station modem, was also cabled to the embedded computer and polled data from each soil water sensing station (described in more detail later in this section) and from the weather station. Data from the latter network was established on the PakBus communication protocol (Campbell Scientific) at a bandwidth of $900 \mathrm{MHz}$. At midnight, the computer automatically built a prescription map if the pivot lateral had moved around the field. A serial connection between the embedded computer and the Pro2 control panel enabled uploading of the prescription map after it was reviewed or modified by the user.

The IRT network consisted of a moving array of twelve IRTs located on the pivot lateral and two stationary IRTs located in a well-watered area (non-stressed) of the field. The

Table 1. Agronomic details for the 2018 and 2019 growing seasons.

\begin{tabular}{|c|c|c|}
\hline Event & 2018 Growing Season & 2019 Growing Season \\
\hline Planting & 5-7 April & 3-5 April \\
\hline Fertilizer & $\begin{array}{l}28 \text { March: applied } 336 \mathrm{~kg} \mathrm{P} \mathrm{ha}^{-1} \text { and } 71 \mathrm{~kg} \mathrm{~N} \mathrm{ha}^{-1} \text {. } \\
26 \text { May: applied } 56 \mathrm{~kg} \mathrm{~N} \mathrm{ha}^{-1} \text { through the center pivot } \\
\text { at } 0.98 \mathrm{~L} \mathrm{~min}^{-1} \text {; potatoes were beginning to flower. }\end{array}$ & Applied $219 \mathrm{~kg} \mathrm{P} \mathrm{ha}^{-1}$ and $108 \mathrm{~kg} \mathrm{~N} \mathrm{ha}^{-1}$. \\
\hline Herbicide & $\begin{array}{l}\text { 8 April: applied Brawl II at } 266 \mathrm{~L} \mathrm{ha}^{-1} \text {. } \\
\text { 9 May: applied Section Three at } 0.37 \mathrm{~L} \mathrm{ha}^{-1} \\
\text { to kill volunteer corn. }\end{array}$ & $\begin{array}{l}28 \text { March: applied Trifluralin at } 2.8 \mathrm{~L} \mathrm{ha}^{-1} \text {. } \\
8 \text { April: applied Eptam } 7 \mathrm{E} \text { at } 4.7 \mathrm{~L} \mathrm{ha}^{-1}, \text { Dual II Mag } \\
\text { at } 1 \mathrm{~L} \mathrm{ha}^{-1} \text {, and Prowl } \mathrm{H} 2 \mathrm{O} \text { at } 3.5 \mathrm{~L} \mathrm{ha}^{-1}\end{array}$ \\
\hline Pesticide & None applied & 9 July (DOY 190): applied Brigade EC at $1.2 \mathrm{~L} \mathrm{ha}^{-1}$ \\
\hline
\end{tabular}


IRTs on the lateral were attached to vertical masts on the sprinkler pipeline, with each mast built with a horizontal offset of $4 \mathrm{~m}$, to allow the IRTs to view a dry canopy as the lateral rotated across the field. Two wireless IRTs were located at the borders of each management zone (MZ), facing inward toward the center of the $\mathrm{MZ}$ at an oblique angle to nadir, viewing the canopy (fig. 2). Further details about the ISSCADA wireless sensor networks (WSNs) were also provided by O'Shaughnessy et al. (2015, 2017).

A daily reference temperature curve was established from the readings of the stationary IRTs. The reference temperature curve was used to scale each one-time-of-day remote temperature measurement $\left(T_{r m t, t}\right)$ and the measured reference temperature $\left(T_{r e f, t}\right)$ made at the same time to predict temperature at each MZ for any daylight time $t\left(T_{r m t}\right)$ (Peters and Evett, 2004):

$$
T_{r m t}=T_{e}+\frac{\left(T_{r m t, t}-T_{e}\right)\left(T_{r e f}-T_{e}\right)}{T_{r e f, t}-T_{e}}
$$

where $T_{e}$ is the predawn canopy temperature, measured at 5:45 h (by the stationary IRTs) and assumed to be the same for the canopy throughout the field at this time, and $T_{r e f}$ is the reference temperature at all other times measured throughout the day. All temperatures are in ${ }^{\circ} \mathrm{C}$.

The weather station measured air temperature, relative humidity $(\mathrm{RH})$, solar irradiation, wind speed $\left(\mathrm{m} \mathrm{s}^{-1}\right)$, and precipitation (mm) using a CR1000 datalogger (Campbell Scientific) that sampled readings from each sensor every $5 \mathrm{~s}$ and averaged the data every $1 \mathrm{~min}$.

\section{IRRIGATION SCHEDULING METHODS Manual Control}

Manual-control irrigations were scheduled every two to three days as needed in a 7-day period to replenish $100 \%$, $80 \%$, and $60 \%$ (designated $\mathrm{M}_{100}, \mathrm{M}_{80}$, and $\mathrm{M}_{60}$, respectively) of soil water depletion to field capacity in the top $1.5 \mathrm{~m}$ of the soil profile. Soil water content from the $\mathrm{M}_{100}$ plots was determined weekly using a neutron probe (NP) (503DR1.5, Instrotek, Campbell Pacific Nuclear, Martinez, Cal.) in $0.2 \mathrm{~m}$ increments from 0.10 to $2.3 \mathrm{~m}$. Soil water readings in the $\mathrm{M}_{80}$ and $\mathrm{M}_{60}$ treatment plots were taken every 30 days and for the day after harvest. The NP was field-calibrated to an accuracy of better than $0.01 \mathrm{~m}^{3} \mathrm{~m}^{-3}$, resulting in separate calibrations for three distinct soil layers (Ap, Bt, and Btca) using methods described by Evett (2008). Irrigation amounts for the $\mathrm{M}_{80}$ and $\mathrm{M}_{60}$ treatment plots were based on readings from the $\mathrm{M}_{100}$ treatment plots and were calculated as $80 \%$ and $60 \%$ replenishment of soil water depletion to field capacity, respectively. Precipitation occurring prior to irrigation of the total amount for the 7-day period was subtracted from the required total.

\section{Plant Feedback Treatment}

The plant feedback method was based on the iCWSI. Predicted canopy temperatures from the scaling algorithm described previously were used to calculate the iCWSI for each remote location $(r)$ :

$$
\operatorname{iCWSI}_{r}=\sum_{i=1}^{N} \frac{\left(T_{r m t}-T_{a}\right)-\left(T_{c}-T_{a}\right)_{l l}}{\left(T_{c}-T_{a}\right)_{u l}-\left(T_{c}-T_{a}\right)_{l l}}
$$

where $N$ is the total number of times the reference canopy temperature was measured from 9:00 $\mathrm{h}$ through 19:00 $\mathrm{h}$ (at

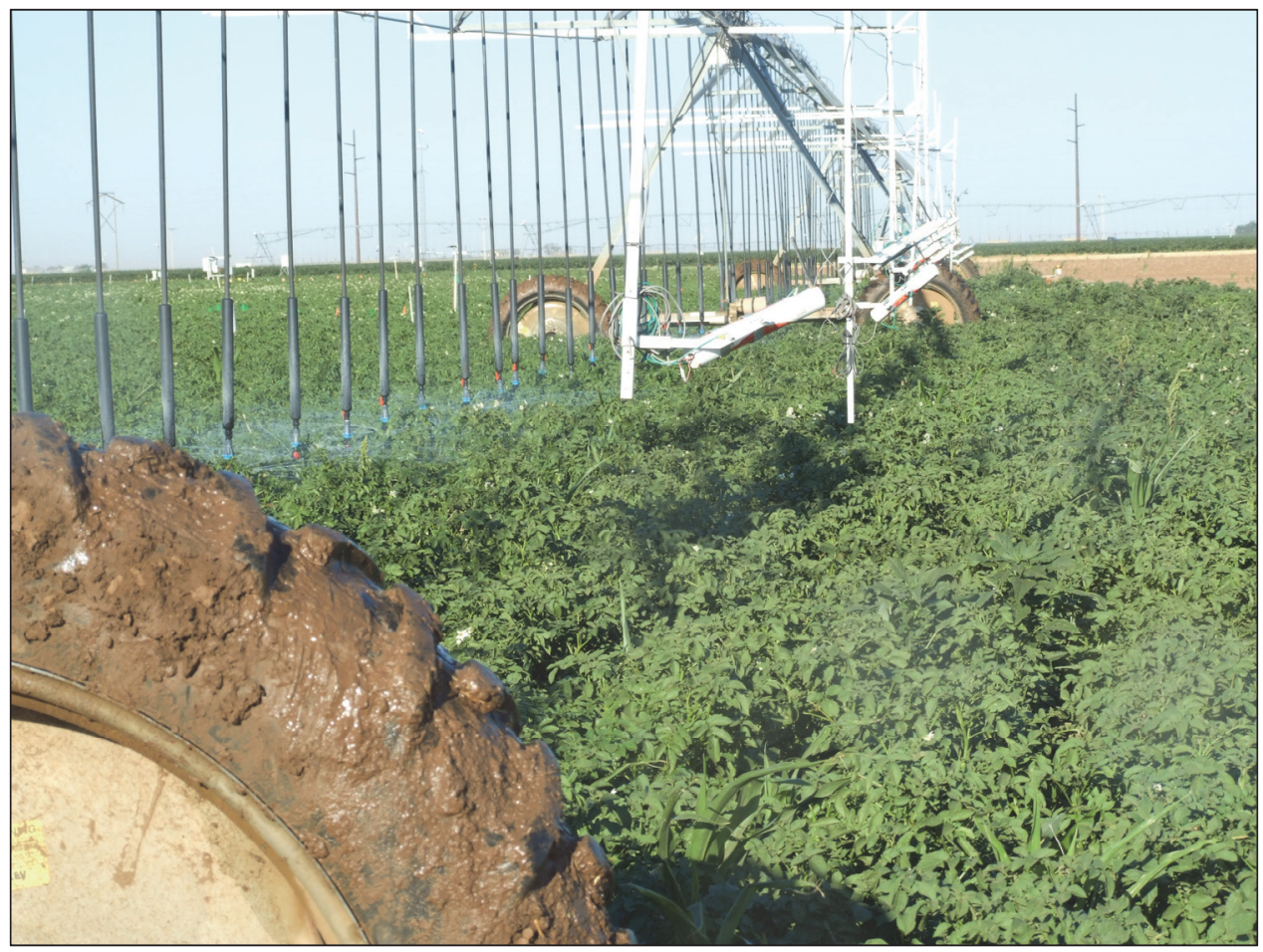

Figure 2. Three-span ISSCADA system outfitted with twelve wireless infrared thermometer sensors (IRTs) viewing a dry potato canopy ahead of the sprinkler assembly. The IRTs are recording canopy temperature while the system moves across the field. 
1 min intervals), $T_{a}$ is the air temperature, $\left(T_{c}-T_{a}\right)_{l l}$ is the estimated temperature of a fully transpiring canopy, and $\left(T_{c}-T_{a}\right)_{u l}$ is the estimated temperature of a non-transpiring canopy, as defined by Jackson et al. (1981).

A three-tiered approach of pre-established thresholds of the iCWSI and corresponding irrigation amounts was used for decision support of irrigation timing and amount (table 2). The thresholds were derived using CWSI values reported in the literature. To establish the minimum threshold, data from well-watered potato plants were considered. Data from Rud et al. (2014) and Gerhards et al. (2016) indicated that the mean CWSI for well-watered potatoes was 0.375 and 0.33 , respectively. Ramírez et al. (2016) recommended that a CWSI of 0.4 not be exceeded when scheduling irrigations to avoid water stress in potatoes. The mean value of these "minimum" reported thresholds is 0.3625 , an iCWSI of this value for $600 \mathrm{~min}$ (the number of minutes for which we calculate an iCWSI) and rounded to the nearest ten $=220$. To establish a maximum threshold, data reported on moderately stressed potatoes were considered. The data from Gerhards et al. (2016) demonstrated that the maximum CWSI for a fully irrigated potato crop after 7 days of withholding irrigation was 0.48, and Ramírez et al. (2016) reported that a CWSI $=0.7$ was approaching a severely stressed potato plant. The mean of these CWSI values multiplied by 600 and rounded to the nearest ten $=350$. The medium threshold was established by choosing a value that was approximately halfway between the minimum and maximum thresholds. Because the iCWSI had not been previously used for irrigation management, these threshold values were considered experimental.

On days when the ISSCADA system traveled around any part of the cropped field, the incoming data streams were managed at midnight. For each treatment plot designated $\mathrm{C}$ (plant feedback), the average calculated iCWSI was compared with the ISSCADA-plant feedback thresholds (table 2) to determine the application depth to be applied. If the iCWSI threshold was $<220$ for a management zone (MZ) designated $\mathrm{C}$, then no irrigation would be recommended for that specific zone. However, if $220<\mathrm{iCWSI} \leq 300$, then the minimum amount of irrigation (for the specified irrigation treatment level) would be recommended. The medium irrigation amount would be recommended if $300<\mathrm{iCWSI} \leq$ 350 , and the maximum irrigation amount would be recommended if iCWSI $>350$.

The maximum irrigation depth for the $\mathrm{C}_{100}$ treatment was based on the near-maximum amount applied on this centerpivot field without causing runoff, which was $25.4 \mathrm{~mm}$ in 2018 when the field was furrow-diked and $20.3 \mathrm{~mm}$ in 2019

Table 2. Thresholds of iCWSI for ISSCADA-plant feedback irrigation scheduling for potatoes at Bushland, Texas, in 2018 and 2019.

\begin{tabular}{ccccc}
\hline & & \multicolumn{3}{c}{ Irrigation Amount to Apply (mm) } \\
\cline { 2 - 4 } Year and Irrigation Treatment & $\begin{array}{c}\text { Minimum Threshold } \\
(220<\mathrm{iCWSI} \leq 300)\end{array}$ & $\begin{array}{c}\text { Medium Threshold } \\
(300<\mathrm{iCWSI} \leq 350)\end{array}$ & $\begin{array}{c}\text { Maximum Threshold } \\
(\mathrm{iCWSI}>350)\end{array}$ \\
\hline 2018 & $\mathrm{C}_{100}$ & 15.2 & 20.3 & 25.4 \\
& $\mathrm{C}_{80}$ & 12.1 & 15.2 & 20.3 \\
& $\mathrm{C}_{60}$ & 9.1 & 12.1 & 15.2 \\
\hline 2019 & $\mathrm{C}_{100}$ & 12.1 & 15.2 & 20.3 \\
& $\mathrm{C}_{80}$ & 9.1 & 12.1 & 15.2 \\
& $\mathrm{C}_{60}$ & 7.2 & 9.1 & 12.1 \\
\hline
\end{tabular}

when furrow-diking was avoided to enhance the performance of the applied herbicides. The depth associated with the medium threshold for the $\mathrm{C}_{100}$ treatment in 2018 was $20.3 \mathrm{~mm}(80 \%$ of $25.4 \mathrm{~mm})$, and the amount associated with the minimum threshold in 2018 was $15.2 \mathrm{~mm}(60 \%$ of $25.4 \mathrm{~mm})$. The calculations for irrigation depths in 2019 followed the same method, i.e., the irrigation depths for the $\mathrm{C}_{80}$ treatment plots were $80 \%$ of the maximum, medium, and minimum depths for the $\mathrm{C}_{100}$ treatment plots, and the irrigation depths for the $\mathrm{C}_{60}$ treatment plots were $60 \%$ of the maximum, medium, and minimum depths for the $\mathrm{C}_{100}$ treatment plots (table 2).

\section{Hybrid Treatment: Plant Feedback and Soil Water Sensing}

A total of nine soil water sensing stations were installed in each year of the study (2018 and 2019), with one set of soil water sensors located in each type of ISSCADA-hybrid treatment plot in each of the three treatment blocks (a, b, and c). The ISSCADA-hybrid treatment plots were designated $\mathrm{H}_{x}$, where $x$ represents the irrigation treatment level, i.e., $100 \%, 80 \%$, or $60 \%$ replenishment of soil water depletion (SWD) (eq. 3) to field capacity, achieved using plant and soil water sensing feedback. The three treatment blocks (a, b, and c) were established to address slight elevation differences and any other field variability. The letter "s" in the plot plan indicates the location of a soil water sensing station (fig. 1). sealed lead acid battery, a datalogger with an internal 900 $\mathrm{MHz}$ spread-spectrum radio (CR206X, Campbell Scientific), a $10 \mathrm{~W}$ solar panel (SP10-LQ, Campbell Scientific), and a $900 \mathrm{MHz}$ Yagi antenna (Larsen YA6900W, Campbell Scientific) in a weather-proof enclosure $(30.5 \mathrm{~cm} \times 25.4 \mathrm{~cm}$ $\times 15.24 \mathrm{~cm}$ ). Each soil water sensing station used four TDR soil water sensors (TDR-315L, Acclima, Inc.), one each installed at depths of 10,20,40, and $80 \mathrm{~cm}$, to sense soil water in the effective rooting depth, which for potatoes ranges from 60 to $95 \mathrm{~cm}$ as reported in the literature (Unlu et al., 2006; Ahmadi et al., 2010). An opening was trenched along one side of the plant bed where the sprinkler drop hose traveled. The two deepest sensors were installed vertically with the mid-point of the length of the steel rods of the TDR placed at depths of 40 and $80 \mathrm{~cm}$, respectively. The two TDR sensors nearest the surface were installed horizontally into the plant bed between plants. Data from the soil water sensing stations were collected at the embedded computer using Loggernet software (ver. 4.5, Campbell Scientific) to poll each soil water sensing station on an hourly basis. Soil water sensing stations similar to those described above were installed in plots 27,34 , and 38 to continuously monitor soil water storage for a different study. The chosen TDR sensor Each of the nine soil water sensing stations contained a $12 \mathrm{~V}$ 
has been shown to be accurate in several different soil types and textures, including Pullman clay loam (Schwartz et al., 2016; Evett et al., 2019).

In each block (fig. 1), there were two hybrid treatment plots designated at the same irrigation level. Calculated soil water depletion from the plot with the soil water sensing station and iCWSI values from both plots were used to provide feedback for irrigation management of the paired hybrid plots (e.g., in block a, the $\mathrm{H}_{100}$ plots were plots 14 and 24, the $\mathrm{H}_{80}$ plots were plots 17 and 21 , and the $\mathrm{H}_{60}$ plots were plots 20 and 23). In 2018, the maximum SWD threshold (Threshold max $_{\text {) }}$ (table 3 ) was established at $50 \%$ of plantavailable water in the soil profile with the goal of increasing IWP, as shown by Kashyap and Panda (2003). Plant-available water (in $\mathrm{cm}$ ) was calculated for each soil layer as the difference between the water content at wilting point and the water content at field capacity multiplied by the layer thickness (in $\mathrm{cm}$ ). In 2019, the SWD Threshold $\max _{\text {mas }}$ weduced to $35 \%$, as in FAO 56 (Allen et al., 1998), after determining that the management-allowable depletion (MAD) level at $50 \%$ SWD resulted in less than optimal soil water levels for the treatment plots managed by the ISSCADA-hybrid method in 2018.

If the SWD was less than a threshold of $10 \%$, irrigation was withheld (table 3 ). If $0.1<\mathrm{SWD}<$ Threshold $_{\max }$, then the calculated mean iCWSI values for the two paired plots were compared with the ISSCADA-plant feedback thresholds corresponding to the same irrigation treatment level to determine the amount of irrigation to apply (table 2).

Soil water depletion (SWD, cm) was calculated by summing the depletion for each soil layer using data from the TDR soil water sensors located at each of the four sensor depths $(i)$ in equation 3 :

$$
\mathrm{SWD}=\sum_{i=1}^{4} x_{i}\left(\frac{\theta_{F C i}-\theta_{v i}}{\theta_{F C i}-\theta_{P W P i}}\right)
$$

where $\theta_{v i}, \theta_{F C i}$, and $\theta_{P W P i}$ are the sensed volumetric water content, water content at field capacity (FC), and water content at permanent wilting point (PWP), respectively, of each soil layer $i$ listed in table 4 (Unger, 1996; Heng et al., 2009; Schwartz et al., 2003; Tolk et al., 2012) for each soil layer $x_{\mathrm{i}}$, where $x$ is the thickness of the soil layer $(\mathrm{cm})$ with midpoint at depth $i$. Computing SWD with $\theta_{v i}=\theta_{P W P}$ gives the maximum depth of SWD $\left(\mathrm{SWD}_{\max }\right)$ in $\mathrm{cm}$ (table 4$)$. The percentage $\mathrm{SWD}=100 \times \mathrm{SWD} / \mathrm{SWD}_{\max }$. All sensors were installed when the crop was approximately $15 \mathrm{~cm}$ tall.

At midnight, after the ISSCADA system traveled across the field, in a wet or dry mode, a dynamic prescription map was built automatically for each irrigation treatment plot. Manual-control plots prescribed the maximum irrigation depth for the designated irrigation level (25.4, 20.3, and $15.2 \mathrm{~mm}$ in 2018 and 20.3, 15.2, and $12.1 \mathrm{~mm}$ in 2019) for the $\mathrm{M}_{100}, \mathrm{M}_{80}$, and $\mathrm{M}_{60}$ treatment plots, respectively. If necessary, the depths for the manual-control plots were changed using the NP data. The irrigation depths for the ISSCADAplant feedback plots and the ISSCADA-hybrid plots were based on exceedance of the thresholds in table 2 and in tables 2 and 3, respectively.

\section{Calculations and Statistical Methods}

Sampling at harvest was done by hand in a $10 \mathrm{~m}^{2}$ area of each plot. Potatoes were harvested on DOY 232 to 235 (20 to 23 August 2018) and on DOY 210 to 217 (29 July to 5 August 2019). The sampling protocol included a plant count, and samples were taken in a $10 \mathrm{~m}^{2}$ area near the NP access tube of each treatment plot. The number of tubers and the fresh weight of each tuber from ten plants within the $10 \mathrm{~m}^{2}$ area were recorded. Tuber yield, $\mathrm{ET}_{c}$ (eq. 4), CWP (eq. 5), and IWP (eq. 6) were determined for each plot after harvesting.

Seasonal crop water use was calculated using the soil water balance equation:

$$
\mathrm{ET}_{c}(\mathrm{~mm})=P+I+F-\Delta S-R
$$

where $P$ is the precipitation $(\mathrm{mm})$ received during the growing season, $I$ is the irrigation amount applied, $F$ is the flux across the lower boundary of the control volume, $\Delta S$ is the seasonal change in soil water storage to a $2.4 \mathrm{~m}$ depth, and $R$ is the runoff, as discussed by Evett (2008), all in mm. Flux was considered to be zero as ascertained by the NP readings down to $2.3 \mathrm{~m}$, while $R$ was assumed to be zero due to furrow-diking, the use of low-elevation spray application (LESA), and irrigation events that did not exceed the soil water infiltration capacity.

Table 3. Soil water and plant feedback sensing thresholds for the hybrid irrigation scheduling method of potatoes at Bushland, Texas, in 2018 and

\begin{tabular}{|c|c|c|c|}
\hline $\begin{array}{c}\text { Irrigation Treatment } \\
\text { Level }\end{array}$ & $\begin{array}{l}\text { If SWD } \leq 10 \% \text {, apply } \\
\text { irrigation amount (mm) }\end{array}$ & If $10 \%<$ SWD $<$ Threshold $_{\max }$ & $\begin{array}{l}\text { If } S W D \geq \text { Threshold }_{\max } \text {, apply } \\
\text { irrigation amount }(\mathrm{mm})\end{array}$ \\
\hline $\begin{array}{c}\mathrm{H}_{100} \\
\mathrm{H}_{80} \\
\mathrm{H}_{60}\end{array}$ & $\begin{array}{l}0.0 \\
0.0 \\
0.0\end{array}$ & $\begin{array}{l}\text { Use iCWSI threshold and apply } \\
\text { irrigation levels shown in table } 2\end{array}$ & $\begin{array}{l}25.4(2018) / 20.3(2019) \\
20.3(2018) / 15.2(2019) \\
15.2(2018) / 12.1(2019)\end{array}$ \\
\hline
\end{tabular}
2019 (SWD = soil water depletion in the top $80 \mathrm{~cm}$ of the soil profile).

Table 4. Sensor depth, layer thickness, and volumetric water content for permanent wilting point (PWP) and field capacity (FC) for each layer for soil under three-span center pivot at Bushland, Texas.

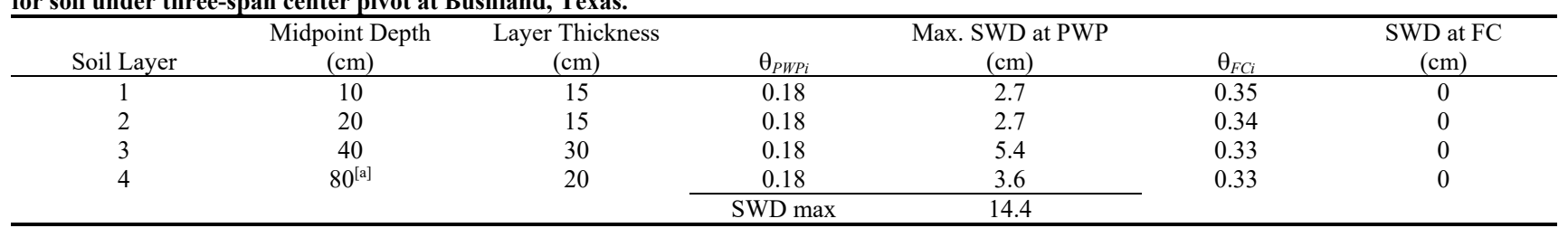

\footnotetext{
a] Assumed reading at $80 \mathrm{~cm}$ is for 60 to $80 \mathrm{~cm}$.
} 
Crop water productivity (CWP) was defined as:

$$
\operatorname{CWP}\left(\mathrm{kg} \mathrm{m}^{-3}\right)=\frac{\text { Yield }(\text { tuber })}{E T_{c}}
$$

Irrigation water productivity was defined as:

$$
\operatorname{IWP}\left(\mathrm{kg} \mathrm{m}^{-3}\right)=\frac{\text { Yield }(\text { tuber })}{\text { Cumulative seasonal irrigation }}
$$

Results were analyzed by growing season using the Mixed Models procedure in SAS (ver. 9.4, SAS Institute, Cary, N.C.) with the main effects of irrigation method and irrigation level treated as fixed effects; sprinkler zones and blocks were considered random effects. Differences among means of fixed effects were compared using the least square means method, and the Bonferroni test was used to provide a pairwise comparison of treatment means at the $p \leq 0.05$ level.

\section{RESULTS AND DISCUSSION Climate Data, Plant Growth STAGES, AND IRRIGATIONS}

Limited rainfall and high maximum daily air temperatures occurred throughout the early part of the 2018 growing season (table 5), requiring two post-plant uniform irrigation events (each $25.4 \mathrm{~mm}$ ) on DOY 116 (26 April) and 119 (29 April) to ensure uniform emergence, which occurred on DOY 120 (30 April). Irrigations based on the ISSCADA system were initiated on DOY 150 (30 May). Buds at the first inflorescence occurred on DOY 152 (1 June), tuber initiation was observed on DOY 156 (5 June) from destructive sampling, mean peak plant height $(67.8,63.1$, and $59.7 \mathrm{~cm}$ for the $\mathrm{I}_{100}, \mathrm{I}_{80}$, and $\mathrm{I}_{60}$ treatment plots, respectively) occurred near DOY 172 (21 June), and tuber bulking progressed through DOY 202 (21 July). Irrigations were terminated on DOY 203 (22 July), and vine death was observed by DOY 212 (1 August) for the 2018 growing season.

In 2019, one uniform irrigation of $16.5 \mathrm{~mm}$ was applied after planting on DOY 138 (18 May); however, irrigations were withheld afterward through DOY 163 (12 June) due to frequent precipitation from DOY 140 to 157 (20 May to 6 June). Differential irrigations using the ISSCADA system were initiated on DOY 164 (13 June) and continued through DOY 201 (20 July). There was no measurable precipitation from DOY 191 to 206 (10 to 25 July), and maximum daily air temperatures rose steadily. Emergence occurred on DOY 122 (2 May), and tuber initiation was observed on DOY 149 (29 May), as revealed by destructive plant sampling. Seventy percent flowering of the first florescence occurred on DOY 154 (3 June), and tuber bulking began near DOY 161 (10 June) and progressed through DOY 200 (19 July). Mean maximum plant height was recorded on DOY 168 (17 June) with heights of $66,65.5$, and $66.9 \mathrm{~cm}$ for the $\mathrm{I}_{100}, \mathrm{I}_{80}$, and $\mathrm{I}_{60}$ treatment plots, respectively. Plant senescence began soon after 19 July 2019, which was approximately 11 days earlier compared with the 2018 growing season. The early necrosis may have been due to heat stress and the droughty conditions (O'Brien and Rich, 1979) that occurred on 10 to 25 July 2019.

In 2018, the mean cumulative seasonal irrigation amounts were 547,445 , and $368 \mathrm{~mm}$ for the $\mathrm{I}_{100}, \mathrm{I}_{80}$, and $\mathrm{I}_{60}$ manualcontrol plots, respectively; 498,418 , and $360 \mathrm{~mm}$ for the $\mathrm{I}_{100}$, $\mathrm{I}_{80}$, and $\mathrm{I}_{60}$ ISSCADA-plant feedback treatment plots, respectively; and 504, 456, and $381 \mathrm{~mm}$ for the $\mathrm{I}_{100}, \mathrm{I}_{80}$, and $\mathrm{I}_{60}$ ISSCADA-hybrid plots, respectively. Mean cumulative irrigation amounts for plots at the $100 \%$ irrigation treatment level managed with the ISSCADA-plant feedback and ISSCADA-hybrid irrigation scheduling methods were significantly less compared with the manual-control treatment plots at the $\mathrm{I}_{100}$ level. The smaller irrigation amounts resulted in less water in the top $80 \mathrm{~cm}$ of the soil profile in the ISSCADA treatment plots, as shown by the mean NP measurements in each type of treatment plot, designated $\mathrm{M}_{100}$, $\mathrm{H}_{100}$, and $\mathrm{C}_{100}$ (fig. 3).

Data from the TDRs in the ISSCADA-hybrid treatments plots at the $\mathrm{I}_{80}$ and $\mathrm{I}_{60}$ irrigation treatment levels also indicated that the mean soil water storage amounts in the top $80 \mathrm{~cm}$ of the soil profile were less compared with those from the manual-control treatment plots at the same irrigation treatment level, $\mathrm{I}_{80}$ and $\mathrm{I}_{60}$, respectively (data not shown).

From DOY 173 to 202 (30 June to 21 July), nine irrigations were applied to the $\mathrm{M}_{100}$ plots; each plot received nine maximum irrigation depths. In these plots, the SWD levels in the top $80 \mathrm{~cm}$ of the soil profile decreased below $30 \%$ after each irrigation event during this period (fig. 4a). Conversely, the $\mathrm{H}_{100}$ plots (plots 14, 28, and 40) managed by the ISSCADA-hybrid irrigation scheduling method received either a smaller number of irrigations or irrigations at less than the maximum depth during this period (table 6). The irrigations signaled at less than maximum depth (for the

\begin{tabular}{|c|c|c|c|c|c|c|c|c|c|}
\hline \multicolumn{2}{|c|}{$\begin{array}{c}\text { Growing Season } \\
\text { and Month }\end{array}$} & $\begin{array}{l}\text { Min. } \\
\text { RH } \\
(\%)\end{array}$ & $\begin{array}{l}\text { Max. } \\
\text { RH } \\
(\%)\end{array}$ & $\begin{array}{l}\text { Min. } \\
\quad T \\
\left({ }^{\circ} \mathrm{C}\right)\end{array}$ & $\begin{array}{l}\operatorname{Max} . \\
T \\
\left({ }^{\circ} \mathrm{C}\right)\end{array}$ & $\begin{array}{c}\text { Total } \\
\text { Precipitation } \\
(\mathrm{mm})\end{array}$ & $\begin{array}{c}\text { Max. Daily } \\
\text { Solar Radiation } \\
\left(\mathrm{MJ} \mathrm{m}^{-2} \mathrm{~d}^{-1}\right)\end{array}$ & $\begin{array}{l}\text { Wind } \\
\text { Speed } \\
\left(\mathrm{m} \mathrm{s}^{-1}\right)\end{array}$ & $\begin{array}{c}\text { Mean Daily } \\
\mathrm{ET}_{o}{ }^{[\mathrm{a}]} \\
\left(\mathrm{mm} \mathrm{d}^{-1}\right)\end{array}$ \\
\hline \multirow[t]{5}{*}{2018} & April & 37.1 & 100 & 17.1 & 38.5 & 0 & 24.7 & 5.6 & 7.9 \\
\hline & May & 26.7 & 80.8 & 16.8 & 32.6 & 22 & 32.1 & 5.9 & 8.4 \\
\hline & June & 37.2 & 74.3 & 19.7 & 31.4 & 17 & 33.4 & 4.8 & 8.5 \\
\hline & July & 33.6 & 79.4 & 18.6 & 32.3 & 13 & 31.4 & 3.4 & 7.5 \\
\hline & August & 33.0 & 82.5 & 17.8 & 32.4 & 57 & 29.9 & 3.9 & 5.5 \\
\hline \multirow[t]{5}{*}{2019} & April & 53.8 & 100 & 8.3 & 31.1 & 81 & 21.1 & 4.7 & 5.1 \\
\hline & May & 42.4 & 90.5 & 10.1 & 24.0 & 151 & 21.7 & 4.5 & 4.4 \\
\hline & June & 34.5 & 85.0 & 14.7 & 30.5 & 85 & 26.2 & 4.5 & 6.7 \\
\hline & July & 29.4 & 83.6 & 18.3 & 33.9 & 71 & 25.5 & 4.1 & 7.2 \\
\hline & August & 29.3 & 83.1 & 18.8 & 34.7 & 17 & 22.5 & 3.8 & 6.5 \\
\hline
\end{tabular}

Table 5. Monthly mean climatic conditions based on daily data for the 2018 and 2019 growing seasons at Bushland, Texas.

[a] Reference evapotranspiration ( $\mathrm{ET}_{o}$ ) for grass calculated using standards of Allen et al. (2005). 


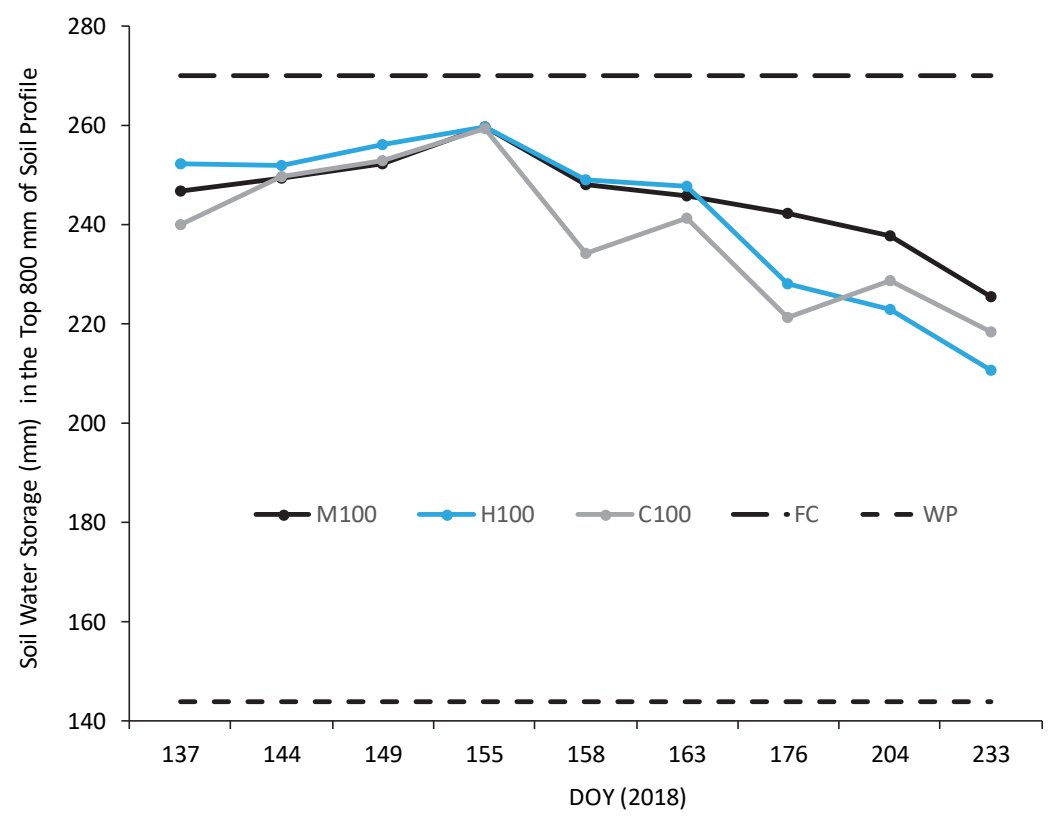

Figure 3. Mean soil water storage for $I_{100}$ plots in the 2018 growing season managed by manual-control irrigation scheduling (M100), ISSCADAhybrid irrigation scheduling $\left(\mathrm{H}_{100}\right)$, and ISSCADA-plant feedback irrigation scheduling $\left(\mathrm{C}_{100}\right)$. Each symbol represents the average of three measurements. FC is water content at field capacity, and WP is water content at permanent wilting point.

ISSCADA-hybrid irrigation scheduling method) were because SWD values were $<50 \%$ and the calculated iCWSI values fell into the minimum threshold range. Reviewing data from the three ISSCADA-plant feedback plots at the $\mathrm{I}_{100}$ treatment level $\left(\mathrm{C}_{100}\right.$ plots), it was determined that $50 \%$ of the calculated $\mathrm{iCWSI}$ values for each $\mathrm{C}_{100}$ treatment plot fell below the maximum threshold range (table 6). The mean calculated iCWSI value for the $\mathrm{C}_{100}$ treatment plots was 281 , and the median value was 275 . At the $I_{80}$ level, the majority of irrigation signals for the ISSCADA-hybrid treatment plots $\left(\mathrm{H}_{80}\right.$ plots) were due to $\mathrm{SWD}>50 \%$; at the $\mathrm{I}_{60}$ level, all $\mathrm{H}_{60}$ treatment plots received the maximum depth because of the exceedance of the maximum SWD threshold. The mean calculated iCWSI values for the $\mathrm{C}_{80}$ and $\mathrm{C}_{60}$ treatment plots were 338 and 388, respectively.

If the SWD threshold had been adjusted to $35 \%$, a greater number of irrigations would have been signaled for ISSCADA-hybrid treatment plots 14 and 28 when $35 \%<$ SWD $<50 \%$ for DOY 181 to 195 (30 June to 14 July), as shown by figures $4 \mathrm{~b}$ and $4 \mathrm{c}$. Conversely, plot 40 showed SWD $>50 \%$ from DOY 188 (7 July) to DOY 195 (14 July); therefore, a reduction of the maximum threshold to $35 \%$ would not have resulted in greater irrigation amounts (fig. 4d). Reducing the maximum SWD depletion to $35 \%$

Table 6. Irrigations applied from DOY 173 to 202 (22 June to 21 July) in 2018 for plot 38 (manual-control irrigation scheduling) and plots managed with ISSCADA-hybrid (H) and ISSCADA-plant feedback (C) irrigation scheduling (NA = not applicable).

\begin{tabular}{|c|c|c|c|c|c|}
\hline $\begin{array}{c}\text { Plot Number } \\
\text { and Irrigation } \\
\text { Scheduling Method }\end{array}$ & $\begin{array}{c}\text { Total } \\
\text { Number of } \\
\text { Irrigations }\end{array}$ & $\begin{array}{c}\text { Number of } \\
\text { Irrigations at } \\
\text { Maximum Depth }\end{array}$ & $\begin{array}{c}\text { Number of } \\
\text { Irrigations at } \\
\text { Medium Depth }\end{array}$ & $\begin{array}{c}\text { Number of } \\
\text { Irrigations at } \\
\text { Minimum Depth }\end{array}$ & $\begin{array}{c}\text { Number of } \\
\text { Irrigations due } \\
\text { to } \mathrm{SWD}>50 \%\end{array}$ \\
\hline $38 \mathrm{M}_{100}$ & 9 & 7 & 2 & 0 & NA \\
\hline $14 \mathrm{H}_{100}$ & 8 & 3 & 0 & 5 & 0 \\
\hline $28 \mathrm{H}_{100}$ & 8 & 4 & 0 & 4 & 0 \\
\hline $40 \mathrm{H}_{100}$ & 9 & 6 & 1 & 2 & 5 \\
\hline $22 \mathrm{C}_{100}$ & 8 & 4 & 0 & 4 & NA \\
\hline $32 \mathrm{C}_{100}$ & 8 & 4 & 1 & 3 & NA \\
\hline $42 \mathrm{C}_{100}$ & 8 & 4 & 0 & 4 & NA \\
\hline $27 \mathrm{M}_{80}$ & 9 & 7 & 2 & 0 & NA \\
\hline $21 \mathrm{H}_{80}$ & 9 & 9 & 0 & 0 & 6 \\
\hline $33 \mathrm{H}_{80}$ & 9 & 9 & 0 & 0 & 7 \\
\hline $46 \mathrm{H}_{80}$ & 8 & 8 & 0 & 0 & 6 \\
\hline $19 \mathrm{C}_{80}$ & 7 & 6 & 2 & 0 & NA \\
\hline $35 \mathrm{C}_{80}$ & 6 & 5 & 0 & 1 & NA \\
\hline $41 \mathrm{C}_{80}$ & 6 & 5 & 0 & 1 & NA \\
\hline $34 \mathrm{M}_{60}$ & 9 & 7 & 2 & 0 & NA \\
\hline $23 \mathrm{H}_{60}$ & 9 & 9 & 0 & 0 & 9 \\
\hline $26 \mathrm{H}_{60}$ & 9 & 9 & 0 & 0 & 9 \\
\hline $37 \mathrm{H}_{60}$ & 9 & 9 & 0 & 0 & 9 \\
\hline $15 \mathrm{C}_{60}$ & 9 & 8 & 0 & 1 & NA \\
\hline $29 \mathrm{C}_{60}$ & 8 & 6 & 1 & 1 & NA \\
\hline $47 \mathrm{C}_{60}$ & 8 & 5 & 2 & 1 & NA \\
\hline
\end{tabular}



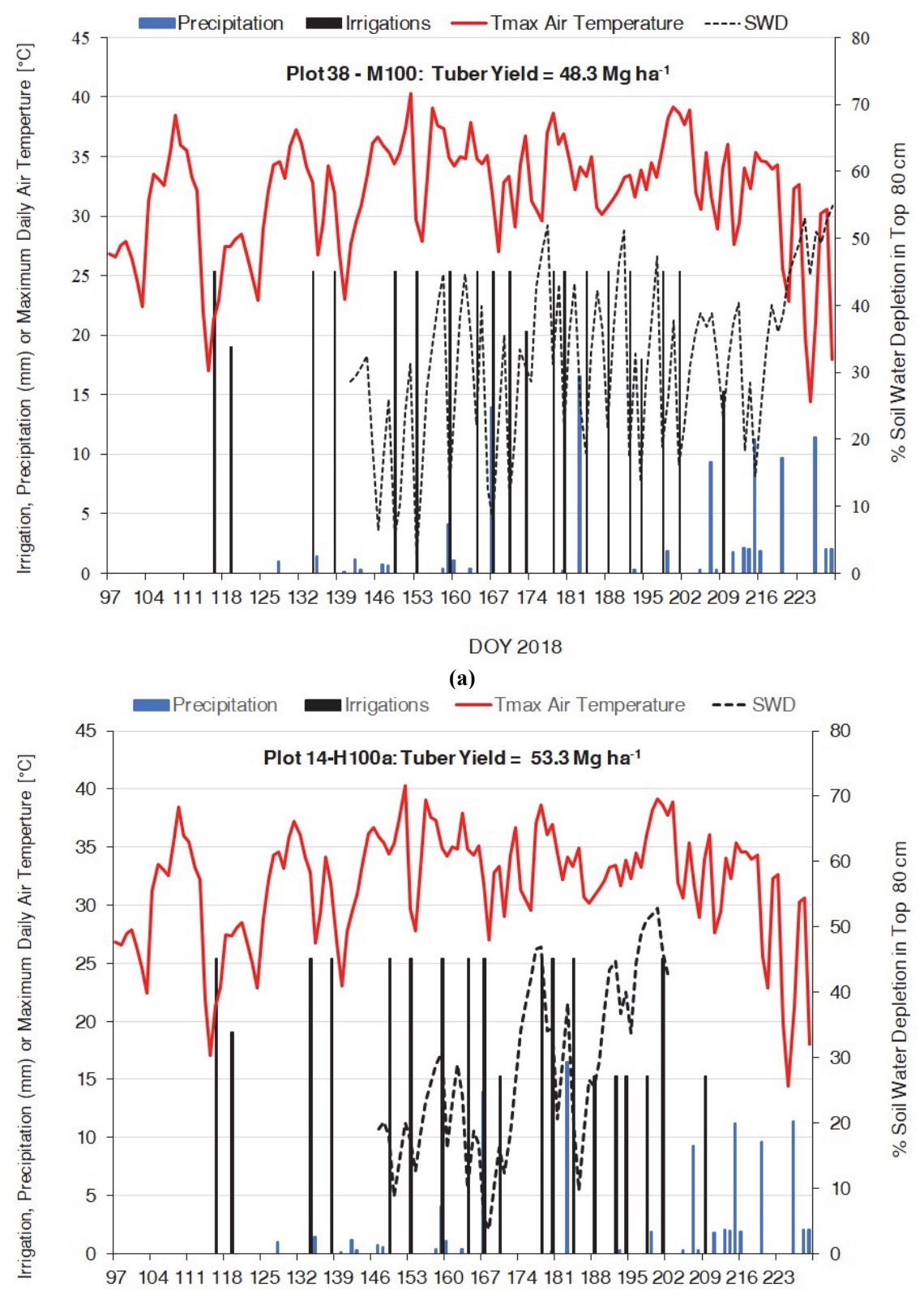

DOY 2018

(b)

Figure 4. Irrigation and precipitation events in 2018, maximum daily air temperature, and soil water depletion (SWD) levels for (a) manualcontrol plot 38 and (b) ISSCADA-hybrid plot 14. All ISSCADA-hybrid plots contained a soil water sensing station.

was in accordance with the soil water depletion fraction recommended in FAO 56 (Allen et al., 1998) and from the positive results demonstrated by Karam et al. (2014), who used a depletion threshold of $35 \%$ of total available water in the root zone $(60 \mathrm{~cm})$ for irrigation scheduling. Similar to the fields at Bushland, Texas, the field in that 2014 study contained high clay content, FC was $0.42\left(\mathrm{~m}^{3} \mathrm{~m}^{-3}\right)$, and PWP was $0.22\left(\mathrm{~m}^{3} \mathrm{~m}^{-3}\right)$. Similarly, more irrigation would have been signaled in the hybrid treatment plots if the iCWSI thresholds had been smaller. The thresholds used were based on the research of others at other locations and may not be wholly appropriate for the Texas High Plains region.

In 2019 , the mean cumulative irrigation amounts were 382,313 , and $244 \mathrm{~mm}$ for the $\mathrm{I}_{100}, \mathrm{I}_{80}$, and $\mathrm{I}_{60}$ manual-control plots, respectively. The mean cumulative irrigation amounts were considerably less for the ISSCADA-plant feedback and ISSCADA-hybrid irrigation scheduling methods for all irrigation treatment levels, as compared with the manual-control irrigation scheduling method. Mean cumulative amounts of 309,258 , and $208 \mathrm{~mm}$ were applied to the $\mathrm{I}_{100}, \mathrm{I}_{80}$, and $\mathrm{I}_{60}$ ISSCADA-plant feedback treatment plots, respectively, while mean cumulative amounts of 322,275 , and $216 \mathrm{~mm}$ were applied to the $\mathrm{I}_{100}, \mathrm{I}_{80}$, and $\mathrm{I}_{60}$ ISSCADA-hybrid plots, respectively. Soil water stored in the top $80 \mathrm{~cm}$ of the soil profile began to decrease so that SWD reached more than $35 \%$ MAD in the $I_{100}$ ISSCADA-plant feedback treatment plots at the beginning of the tuber bulking stage on DOY 169 (18 June) (fig. 5). During the tuber maturation stage (DOY 

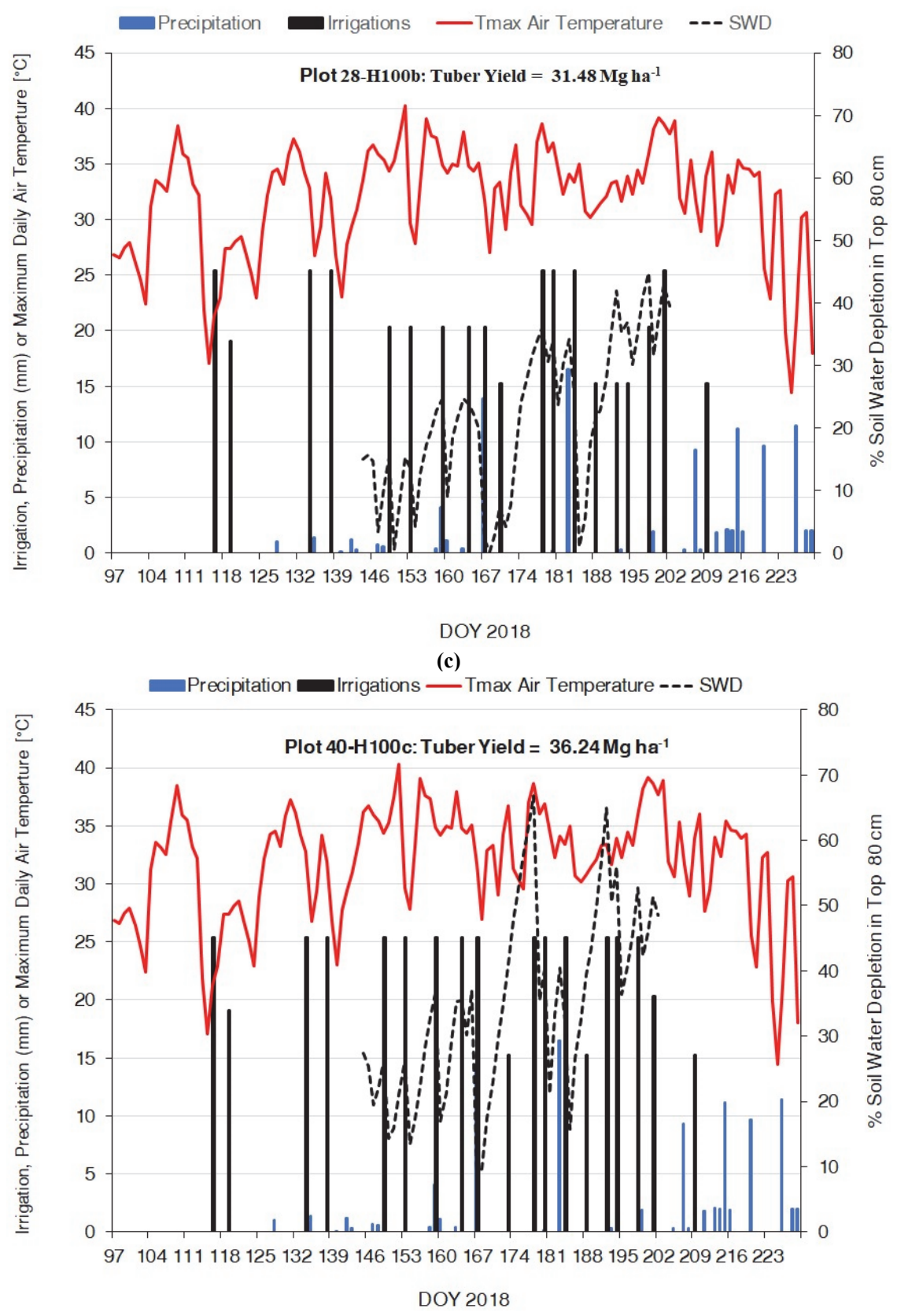

(d)

Figure 4 (continued). Irrigation and precipitation events in 2018, maximum daily air temperature, and soil water depletion (SWD) levels for (c) ISSCADA-hybrid plot 28 and (d) ISSCADA-hybrid plot 40. All ISSCADA-hybrid plots contained a soil water sensing station.

192 to 205,11 to 24 July), the mean soil water stored in top $80 \mathrm{~cm}$ of the soil profile in both the ISSCADA-hybrid and ISSCADA-plant feedback treatment plots was less than the mean value for the manual-control plots (at the $\mathrm{I}_{100}$ level). Soil water data for the $\mathrm{H}_{100}$ and $\mathrm{C}_{100}$ plots were determined by estimating daily crop water use using daily reference evapotranspiration calculated from the nearby weather station, crop coefficients for potatoes from FAO 56 (Allen et al., 1998), and adjusting the data with soil water content measured with the NP. During the tuber bulking through the maturation growth stages, the $\mathrm{M}_{100}$ plots received nine irrigations at the maximum depth $(20.3 \mathrm{~mm})$, while the $\mathrm{H}_{100}$ and $\mathrm{C}_{100}$ plots received a lesser number of irrigations and sometimes irrigations at smaller depths (table 7). Readings from the TDR sensors in plot $28\left(\mathrm{H}_{100}\right)$ (fig. 6a) indicated that soil water levels were lower than in the manual-control treatment plots (fig. 6b) at the beginning of the season, and the majority of irrigations for this plot and that of plot 30 (companion hybrid plot) were based on SWD > Threshold $_{\max }(35 \%)$. However, the SWD levels for plot $14\left(\mathrm{H}_{100}\right)$ (fig. 6c) from the TDR sensors indicated that SWD was maintained at or below 35\%. Irrigations on DOY 198 (17 July) and 199 (18 July) for plots 28 and 30 were based on the ISSCADAplant feedback thresholds because the telemetry system for the soil water sensing station in plot 28 failed.

Data analyzed from the three ISSCADA-plant feedback plots (plots 22, 32 and 42) in the $\mathrm{I}_{100}$ treatment level $\left(\mathrm{C}_{100}\right)$ showed that $29 \%$ to $57 \%$ of the iCWSI values fell below the 


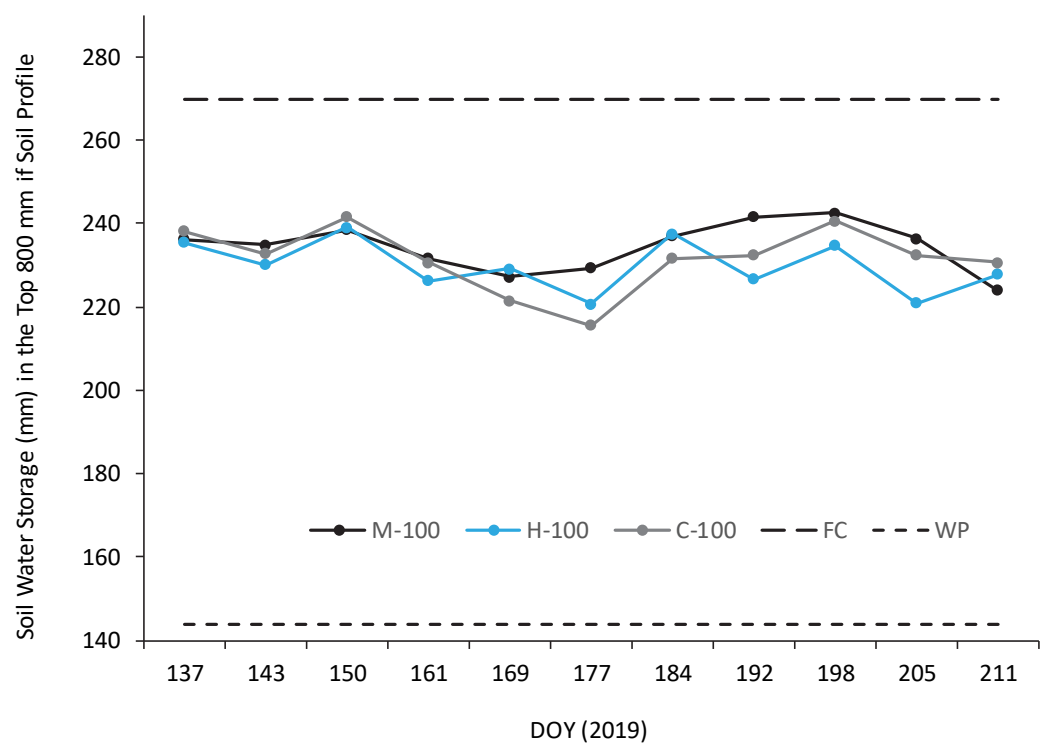

Figure 5. Mean soil water storage for $I_{100}$ plots in the 2019 growing season managed by manual-control irrigation scheduling (M100), ISSCADAhybrid irrigation scheduling $\left(\mathrm{H}_{100}\right)$, and ISSCADA-plant feedback irrigation scheduling $\left(\mathrm{C}_{100}\right)$. Each symbol represents the average of three measurements. FC is water content at field capacity, and WP is water content at permanent wilting point.

maximum threshold range, signaling less than the maximum application depth. The mean and median seasonal iCWSI values were 250 and 237 for the $\mathrm{C}_{100}$ treatment plots, 302 and 339 for the $\mathrm{C}_{80}$ treatment plots, and 321 and 360 for the $\mathrm{C}_{60}$ treatments plots, respectively. Crops in the $\mathrm{I}_{60}$ treatment plots were irrigated at the maximum depth throughout the mid- to late-irrigation season, as the iCWSI and SWD levels for these crops were consistently high, exceeding the maximum established plant feedback and soil water sensing thresholds.

\section{TUBER YIELDS, ET ${ }_{c}$, CWP, IWP,} AND SPECIFIC GRAVITY

Mean tuber yields were based on marketable tubers, i.e., with a circumference between 4.75 and $10.3 \mathrm{~cm}$ (Rens et al.,
2015). In 2018, overall mean tuber yields ranged from 32.3 to $42.0 \mathrm{Mg} \mathrm{ha}^{-1}$ by irrigation scheduling method and from 31.3 to $40.7 \mathrm{Mg} \mathrm{ha}^{-1}$ by irrigation level (table 8). Mean yields were significantly greater in the manual-control treatment plots by $18 \%$ to $25 \%$ as compared with the ISSCADA irrigation scheduling methods. Mean seasonal $\mathrm{ET}_{c}$ was similar between the manual-control and ISSCADA-hybrid methods but significantly less for the ISSCADA-plant feedback method. Tuber yields were less in the ISSCADA-plant feedback treatment plots because a lesser number of irrigations were triggered, which suggests that either (1) the calculated iCWSI values did not reflect the degree to which the water deficit impacted tuber yields, or (2) the iCWSI thresholds were inappropriately large for our region. Mean CWP and mean IWP ranged from 6.8 to $8.3 \mathrm{~kg} \mathrm{~m}^{-3}$ and from 9.5 to

Table 7. Irrigations applied from DOY 169 to 193 (18 June to 12 July) in 2019 for plot 38 (manual-control irrigation scheduling) and plots managed with ISSCADA-hybrid (H) and ISSCADA-plant feedback (C) irrigation scheduling (NA = not applicable).

\begin{tabular}{|c|c|c|c|c|c|}
\hline $\begin{array}{c}\text { Plot Number } \\
\text { and Irrigation } \\
\text { Scheduling Method }\end{array}$ & $\begin{array}{c}\text { Total } \\
\text { Number of } \\
\text { Irrigations }\end{array}$ & $\begin{array}{c}\text { Number of } \\
\text { Irrigations at } \\
\text { Maximum Depth }\end{array}$ & $\begin{array}{c}\text { Number of } \\
\text { Irrigations at } \\
\text { Medium Depth }\end{array}$ & $\begin{array}{c}\text { Number of } \\
\text { Irrigations at } \\
\text { Minimum Depth }\end{array}$ & $\begin{array}{c}\text { Number of } \\
\text { Irrigations due } \\
\text { to } \mathrm{SWD}>35 \%\end{array}$ \\
\hline $38 \mathrm{M}_{100}$ & 9 & 9 & 0 & 0 & NA \\
\hline $14 \mathrm{H}_{100}$ & 8 & 4 & 1 & 3 & 0 \\
\hline $28 \mathrm{H}_{100}$ & 8 & 8 & 0 & 0 & 7 \\
\hline $40 \mathrm{H}_{100}$ & 7 & 3 & 3 & 1 & 2 \\
\hline $22 \mathrm{C}_{100}$ & 8 & 4 & 0 & 4 & 0 \\
\hline $32 \mathrm{C}_{100}$ & 7 & 5 & 0 & 2 & 0 \\
\hline $42 \mathrm{C}_{100}$ & 7 & 3 & 1 & 3 & 0 \\
\hline $27 \mathrm{M}_{80}$ & 9 & 9 & 0 & 0 & NA \\
\hline $21 \mathrm{H}_{80}$ & 9 & 5 & 0 & 4 & 2 \\
\hline $33 \mathrm{H}_{80}$ & 8 & 5 & 0 & 3 & 1 \\
\hline $46 \mathrm{H}_{80}$ & 7 & 6 & 1 & 0 & 3 \\
\hline $19 \mathrm{C}_{80}$ & 6 & 2 & 2 & 2 & NA \\
\hline $35 \mathrm{C}_{80}$ & 8 & 3 & 1 & 4 & NA \\
\hline $41 \mathrm{C}_{80}$ & 6 & 5 & 0 & 1 & NA \\
\hline $34 \mathrm{M}_{60}$ & 9 & 9 & 0 & 0 & NA \\
\hline $23 \mathrm{H}_{60}$ & 9 & 5 & 0 & 4 & 2 \\
\hline $26 \mathrm{H}_{60}$ & 6 & 2 & 1 & 3 & 0 \\
\hline $37 \mathrm{H}_{60}$ & 7 & 7 & 0 & 0 & 5 \\
\hline $15 \mathrm{C}_{60}$ & 9 & 4 & 0 & 5 & NA \\
\hline $29 \mathrm{C}_{60}$ & 6 & 2 & 1 & 3 & NA \\
\hline $47 \mathrm{C}_{60}$ & 8 & 6 & 1 & 1 & NA \\
\hline
\end{tabular}




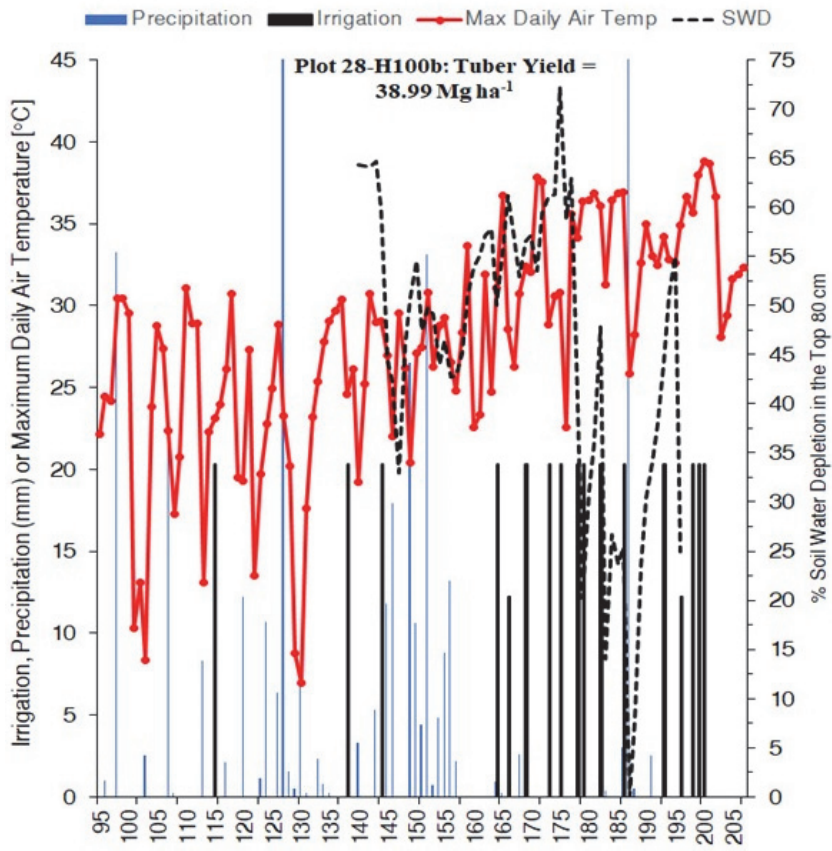

DOY 2019

(a)

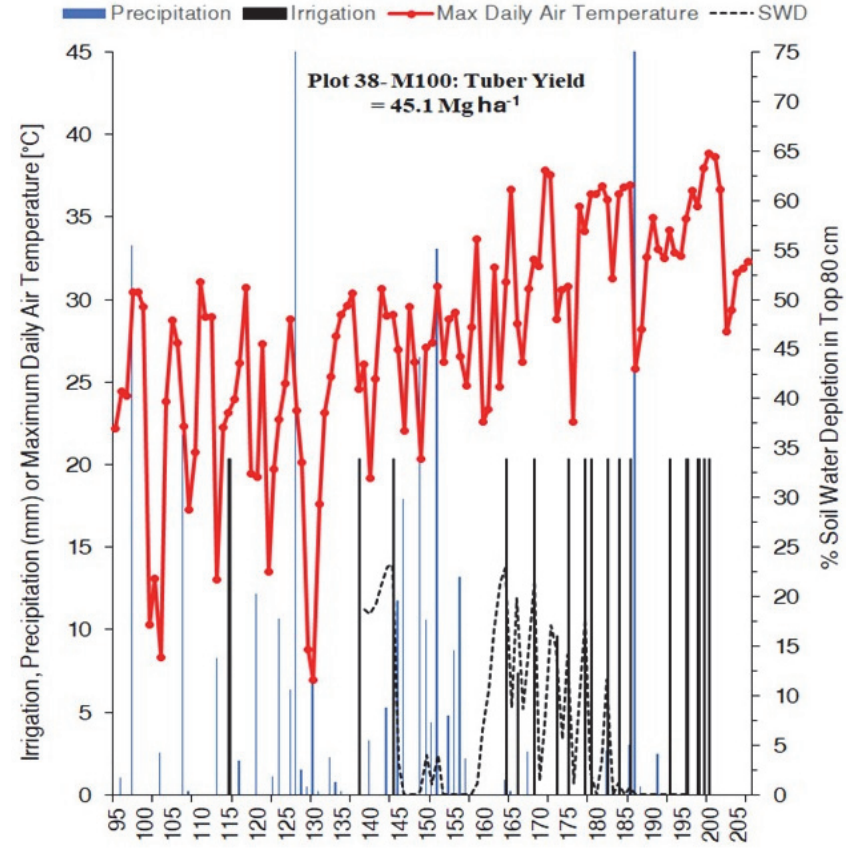

DOY 2019

(b)

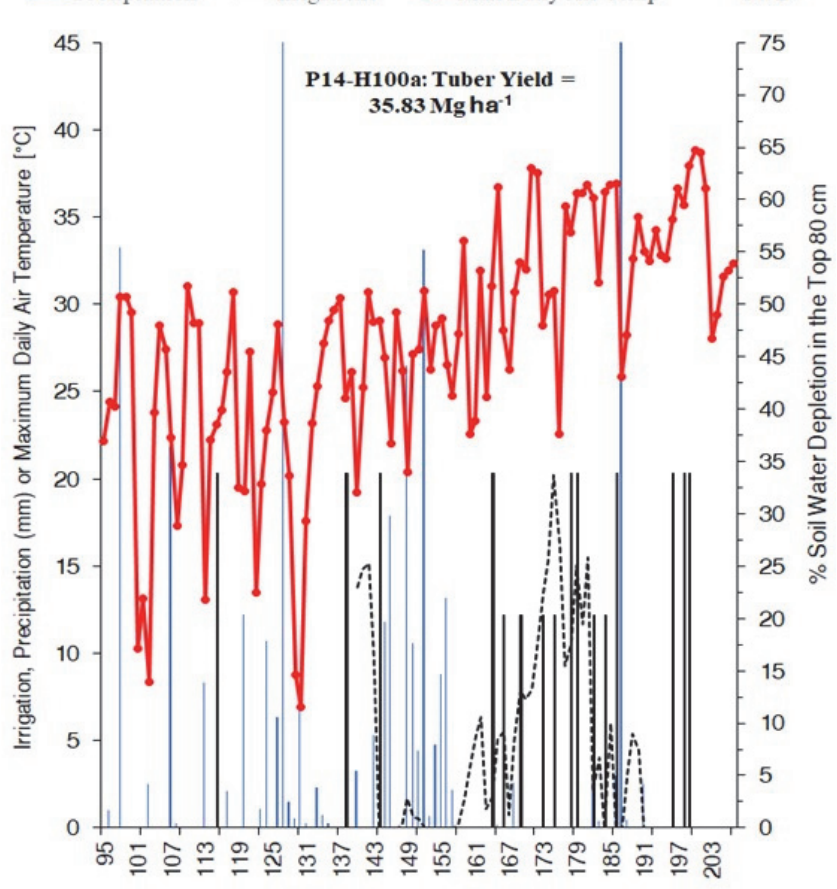

DOY 2019

(c)

Figure 6. Irrigation and precipitation events in 2019, maximum daily air temperature, and soil water depletion (SWD) levels for (a) ISSCADAhybrid plot 28, (b) manual-control plot 38, and (c) ISSCADA-hybrid plot 14.

$11.4 \mathrm{~kg} \mathrm{~m}^{-3}$, respectively, across irrigation scheduling methods and were significantly greater in the manual-control treatment plots as compared with the ISSCADA irrigation scheduling methods (table 8).

Reviewing the results across irrigation treatment levels, the mean tuber yield, mean tuber weight, CWP, and IWP for the $\mathrm{I}_{100}$ and $\mathrm{I}_{80}$ treatment plots were not significantly different. However, at the $\mathrm{I}_{60}$ irrigation level, the mean tuber yield and individual tuber weight were significantly less compared with the $\mathrm{I}_{100}$ treatment plots.

Comparing results for the interaction between irrigation scheduling method and irrigation level, tuber yields were significantly greater for plots in the manual-control method 
Table 8. Crop response to irrigation scheduling methods and irrigation levels for the 2018 and 2019 growing seasons at Bushland, Texas. Means followed by the same letter are not significantly different.

\begin{tabular}{|c|c|c|c|c|c|c|}
\hline & & $\begin{array}{c}\text { Tuber Yield } \\
\left(\mathrm{Mg} \mathrm{ha}^{-1}\right)\end{array}$ & $\begin{array}{c}\text { Mean Tuber Mass } \\
(\mathrm{g})\end{array}$ & $\begin{array}{l}\mathrm{ET}_{c} \\
(\mathrm{~mm}) \\
\end{array}$ & $\begin{array}{c}\mathrm{CWP} \\
\left(\mathrm{kg} \mathrm{m}^{-3}\right)\end{array}$ & $\begin{array}{c}\text { IWP } \\
\left(\mathrm{kg} \mathrm{m}^{-3}\right) \\
\end{array}$ \\
\hline \multirow[t]{18}{*}{2018} & Irrigation scheduling method & & & & & \\
\hline & Manual-control & $42.0 \mathrm{a}$ & $158.7 \mathrm{a}$ & $507 \mathrm{a}$ & $8.3 \mathrm{a}$ & $11.4 \mathrm{a}$ \\
\hline & ISSCADA-plant feedback & $32.3 \mathrm{~b}$ & $146.7 \mathrm{a}$ & $478 \mathrm{~b}$ & $6.8 \mathrm{~b}$ & $9.5 \mathrm{~b}$ \\
\hline & ISSCADA-hybrid & $34.5 \mathrm{~b}$ & $144.4 \mathrm{a}$ & $503 \mathrm{a}$ & $6.9 \mathrm{~b}$ & $9.6 \mathrm{~b}$ \\
\hline & Irrigation level & & & & & \\
\hline & $\mathrm{I}_{100}$ & $40.7 \mathrm{a}$ & $158.8 \mathrm{a}$ & $551 \mathrm{a}$ & $7.4 \mathrm{a}$ & $9.7 \mathrm{a}$ \\
\hline & $\mathrm{I}_{80}$ & $35.5 \mathrm{ab}$ & $150.2 \mathrm{ab}$ & $503 \mathrm{~b}$ & $7.1 \mathrm{a}$ & $9.6 \mathrm{a}$ \\
\hline & $\mathrm{I}_{60}$ & $31.3 \mathrm{~b}$ & $136.6 \mathrm{~b}$ & $440 \mathrm{c}$ & $7.1 \mathrm{a}$ & $10.7 \mathrm{a}$ \\
\hline & Irrigation scheduling method $\times$ Irrigation level & & & & & \\
\hline & $\mathrm{M}_{100}$ & $50.0 \mathrm{a}$ & $168.7 \mathrm{a}$ & $578 \mathrm{a}$ & $8.7 \mathrm{a}$ & $11.1 \mathrm{a}$ \\
\hline & ISSCADA-plant feedback $\times \mathrm{I}_{100}$ & $36.5 \mathrm{bcd}$ & $166.7 \mathrm{a}$ & $535 \mathrm{bc}$ & $6.8 \mathrm{abc}$ & $8.9 \mathrm{~b}$ \\
\hline & $\underline{\text { ISSCADA-hybrid } \times \mathrm{I}_{100}}$ & $38.1 \mathrm{bc}$ & $149.9 \mathrm{a}$ & $546 \mathrm{~b}$ & $7.0 \mathrm{ab}$ & $9.4 \mathrm{ab}$ \\
\hline & $\mathrm{M}_{80}$ & $42.8 \mathrm{ab}$ & $162.5 \mathrm{a}$ & $503 \mathrm{de}$ & $8.5 \mathrm{ab}$ & $11.6 \mathrm{a}$ \\
\hline & ISSCADA-plant feedback $\times \mathrm{I}_{80}$ & $30.8 \mathrm{~cd}$ & $147.6 \mathrm{a}$ & $477 \mathrm{e}$ & $6.4 \mathrm{c}$ & $9.3 \mathrm{ab}$ \\
\hline & $\underline{\text { ISSCADA-hybrid } \times \mathrm{I}_{80}}$ & $34.2 \mathrm{~cd}$ & $145.4 \mathrm{a}$ & $515 \mathrm{~cd}$ & $6.6 \mathrm{c}$ & $9.0 \mathrm{~b}$ \\
\hline & $\mathrm{M}_{60}$ & $33.3 \mathrm{bcd}$ & $144.8 \mathrm{a}$ & $439 \mathrm{fg}$ & $7.6 \mathrm{abc}$ & $11.5 \mathrm{a}$ \\
\hline & ISSCADA-plant feedback $\times \mathrm{I}_{60}$ & $29.6 \mathrm{~d}$ & $125.7 \mathrm{a}$ & $423 \mathrm{~g}$ & $7.0 \mathrm{abc}$ & $10.6 \mathrm{ab}$ \\
\hline & ISSCADA-hybrid $\times \mathrm{I}_{60}$ & $31.0 \mathrm{~d}$ & $137.9 \mathrm{a}$ & $449 \mathrm{f}$ & $6.9 \mathrm{bc}$ & $10.4 \mathrm{ab}$ \\
\hline \multirow[t]{18}{*}{2019} & Irrigation scheduling method & & & & & \\
\hline & Manual-control & $31.6 \mathrm{a}$ & $134.7 \mathrm{a}$ & $647 \mathrm{a}$ & $5.0 \mathrm{a}$ & $10.6 \mathrm{~b}$ \\
\hline & ISSCADA-plant feedback & $32.6 \mathrm{a}$ & $112.0 \mathrm{~b}$ & $592 \mathrm{c}$ & $5.5 \mathrm{a}$ & $12.9 \mathrm{a}$ \\
\hline & ISSCADA-hybrid & $32.1 \mathrm{a}$ & $115.2 \mathrm{~b}$ & $613 b$ & $5.2 \mathrm{a}$ & $12.1 \mathrm{ab}$ \\
\hline & Irrigation level & & & & & \\
\hline & $\mathrm{I}_{100}$ & $33.8 \mathrm{a}$ & $122.2 \mathrm{ab}$ & $667 \mathrm{a}$ & $5.1 \mathrm{a}$ & $10.2 \mathrm{~b}$ \\
\hline & $\mathrm{I}_{80}$ & $34.5 \mathrm{a}$ & $132.5 \mathrm{a}$ & $618 b$ & $5.6 \mathrm{a}$ & $12.4 \mathrm{a}$ \\
\hline & $\mathrm{I}_{60}$ & $28.8 \mathrm{~b}$ & $102.9 \mathrm{~b}$ & $562 \mathrm{c}$ & $5.1 \mathrm{a}$ & $13.1 \mathrm{a}$ \\
\hline & Irrigation scheduling method $\times$ Irrigation level & & & & & \\
\hline & $\mathrm{M}_{100}$ & $36.6 \mathrm{ab}$ & $142.1 \mathrm{ab}$ & $715 \mathrm{a}$ & $5.1 \mathrm{ab}$ & $9.6 \mathrm{c}$ \\
\hline & ISSCADA-plant feedback $\times \mathrm{I}_{100}$ & $32.2 \mathrm{bc}$ & $95.0 \mathrm{bc}$ & $637 \mathrm{bcd}$ & $5.1 \mathrm{ab}$ & $10.4 \mathrm{bc}$ \\
\hline & ISSCADA-hybrid $\times \mathrm{I}_{100}$ & $33.2 \mathrm{bc}$ & $125.9 \mathrm{abc}$ & $659 \mathrm{~b}$ & $5.0 \mathrm{~b}$ & $10.3 \mathrm{c}$ \\
\hline & $\mathrm{M}_{80}$ & $31.7 \mathrm{bc}$ & $148 \mathrm{a}$ & $647 \mathrm{bc}$ & $4.9 \mathrm{~b}$ & $10.1 \mathrm{bc}$ \\
\hline & ISSCADA-plant feedback $\times \mathrm{I}_{80}$ & $37.1 \mathrm{a}$ & $127.3 \mathrm{abc}$ & 593 def & $6.3 \mathrm{a}$ & $14.4 \mathrm{a}$ \\
\hline & 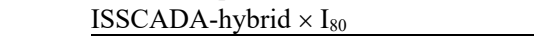 & $34.6 \mathrm{ab}$ & $127.4 \mathrm{ab}$ & $616 \mathrm{cde}$ & $5.6 \mathrm{ab}$ & $12.6 \mathrm{ab}$ \\
\hline & $\mathrm{M}_{60}$ & $29.6 \mathrm{bc}$ & $113.8 \mathrm{abc}$ & 579 ef & $5.1 \mathrm{ab}$ & $12.1 \mathrm{abc}$ \\
\hline & ISSCADA-plant feedback $\times \mathrm{I}_{60}$ & $28.6 \mathrm{bc}$ & $113.6 \mathrm{abc}$ & $545 \mathrm{f}$ & $5.3 \mathrm{ab}$ & $13.8 \mathrm{a}$ \\
\hline & ISSCADA-hybrid $\times \mathrm{I}_{60}$ & $28.4 \mathrm{c}$ & $92.2 \mathrm{c}$ & $563 \mathrm{f}$ & $5.0 \mathrm{~b}$ & $13.2 \mathrm{a}$ \\
\hline
\end{tabular}

at the $\mathrm{I}_{100}$ and $\mathrm{I}_{80}$ levels, but there was no significant difference between irrigation scheduling methods at the $\mathrm{I}_{60}$ level. Irrigation treatment level and irrigation scheduling method did not have a significant effect on tuber mass. Seasonal crop water use $\left(\mathrm{ET}_{c}\right)$ at the $\mathrm{I}_{100}$ level was significantly greater for the manual-control method as compared with both the ISSCADA-plant feedback and ISSCADA-hybrid methods at this irrigation level. In addition, $C W P$ at the $\mathrm{I}_{80}$ level for the manual-control method was significantly greater than for both of the ISSCADA methods. Results were mixed for IWP, with values being similar between the manual-control method and the ISSCADA-hybrid method at the $\mathrm{I}_{100}$ level and similar between the manual-control method and the ISSCADA-plant feedback method at the $\mathrm{I}_{80}$ level. Crop response was not significantly different between irrigation scheduling methods at the $\mathrm{I}_{60}$ level.

In 2019, overall mean tuber yields were not significantly different between irrigation scheduling methods and ranged from 31.6 to $32.6 \mathrm{Mg} \mathrm{ha}^{-1}$. Mean seasonal $\mathrm{ET}_{c}$ was significantly different among irrigation scheduling methods; however, overall mean individual tuber weight was significantly greater for the manual-control treatment plots, meaning that the tubers were larger than those produced with the ISSCADA methods. Mean overall CWP was similar among irrigation scheduling methods, while mean IWP was significantly greater for the ISSCADA-plant feedback method as compared with the manual-control method. Interactions between main treatments were not significant (table 8).

Reviewing the effects of irrigation treatment level, similar to 2018, mean tuber yields in the $\mathrm{I}_{100}$ treatment plots were similar to tuber yields in the $\mathrm{I}_{80}$ treatment plots but significantly greater compared with the $\mathrm{I}_{60}$ treatment plots, despite the greater rainfall amounts in 2019. Mean tuber yields ranged from 28.8 to $34.5 \mathrm{Mg} \mathrm{ha}^{-1}$ across the irrigation treatment levels. There was no significant difference in mean CWP among irrigation treatment levels, and mean IWP was significantly less in the $\mathrm{I}_{100}$ treatment plots as compared with the $\mathrm{I}_{80}$ and $\mathrm{I}_{60}$ treatment plots.

Comparing results for the interaction of irrigation scheduling method and irrigation treatment level, the tuber yields, CWP, and IWP were significantly greater for the ISSCADAplant feedback treatment plots as compared with the manualcontrol treatment plots at the $\mathrm{I}_{80}$ level; however, the results were not significantly different between irrigation scheduling methods at the $\mathrm{I}_{100}$ and $\mathrm{I}_{60}$ levels.

In both years, the mean level of soil water content in the top $80 \mathrm{~cm}$ of the soil profile in the $\mathrm{I}_{100}$ ISSCADA-hybrid and ISSCADA-plant feedback treatment plots were less compared with the mean soil water content in the manual-control 
treatment plots at the $\mathrm{I}_{100}$ and $\mathrm{I}_{80}$ treatment levels. In 2018, soil water depletion levels for treatment plots managed by both ISSCADA methods began to increase at tuber initiation and continued throughout the tuber bulking and maturation stages. The soil water deficit in the root zone during this critical period likely resulted in tuber yield reduction. Problems with tuber bulking and shape are common with higher clay soils under drier conditions. Similar findings were reported by Karam et al. (2014) in that deficit irrigation applied at tuber bulking resulted in a $12 \%$ loss in tuber yield.

In 2019, the period in which soil water depletion for the ISSCADA treatment plots was greatest again coincided with the tuber bulking and tuber maturation growth stages. However, this level of depletion did not significantly decrease tuber yields as compared with yields from the manual-control treatment plots. This result is different from that of Karam et al. (2014), who reported a $42 \%$ loss in tuber yield due to deficit soil water content in the maturation stage. As noted earlier, the 2019 potato crop reached senescence approximately two weeks earlier than in 2018. Van Loon (1981) reported that the maximum tuber production per day is determined by the duration for which a full canopy is maintained. If water stress occurs during this period, it can encourage crop senescence. Robins and Domingo (1956) also reported that lateseason water stress hastens maturity and senescence.

Addressing the secondary objective of the study, the effects of mild deficit irrigation on fresh weight tuber yield agree with those reported by Kifle and Gebretsadikan (2016), who found no significant difference between tuber yields grown in a clay loam soil and irrigated at $100 \%$ and $75 \%$ of full irrigation, and with Ahmadi et al. (2014), who reported no significant tuber yield loss for potatoes irrigated at $75 \%$ of full irrigation in silty clay loam soils. The significant reduction in tuber yields between irrigation treatments at the $\mathrm{I}_{100}$ and $\mathrm{I}_{60}$ levels in this study are similar to the results of Kifle and Gebretsadikan (2016), who also reported that irrigation at $65 \%$ of full significantly reduced tuber yields. Similarly, Ierna and Mauromicale (2018) found that irrigation at $50 \%$ of full, regardless of $\mathrm{N}$ application rate, significantly reduced fresh tuber weight for potatoes grown in a clay loam soil. Kashyap and Panda (2003) reported that irrigations triggered at $60 \%$ and $70 \%$ of MAD resulted in significant yield losses. However, the current study results are different from El-Abedin et al. (2017), who reported that deficit irrigation at $70 \%$ and $50 \%$ of full did not significantly reduce fresh weight tuber yields grown in a sandy loam soil. Mean tuber yields and mean CWP were similar for the $\mathrm{I}_{100}$ and $\mathrm{I}_{80}$ treatment levels, and IWP was significantly greater for the $\mathrm{I}_{80}$ treatment plots in 2019. Water savings of approximately $19 \%$ resulted from irrigating at the $\mathrm{I}_{80}$ level as compared with the $\mathrm{I}_{100}$ level, with only a $13 \%$ reduction in tuber yields in a dry year and no reduction in a wet year.

Results from these contrasting climatic seasons indicate that the two ISSCADA methods did not over-irrigate in either season. This is critical because over-irrigation can result in reduced yields due to waterlogging (Wolfe et al., 1983; Yost et al., 2019) and water wastage. However, in both years, the ISSCADA methods irrigated less than the manualcontrol method at the $\mathrm{I}_{100}$ and $\mathrm{I}_{80}$ treatment levels. In the dry year of 2018, our hypothesis that the ISSCADA-plant feedback method would produce tuber yields that were similar to those of the manual-control method at the $\mathrm{I}_{100}$ level was not realized. However, in the wet year of 2019, the performance of the ISSCADA-plant feedback method was comparable to the manual-control method. The advantages of the ISSCADA-plant feedback method over the manual-control method are that it is less labor and capital intensive, decision support for irrigation scheduling is automatically prepared in the form of dynamic prescription maps, and monitoring of crop water status can cover a larger area than soil water content measurements at static locations. This would be particularly important in fields with large variations in soil texture and hydrology.

The hypothesis that the ISSCADA-hybrid method would optimize irrigation scheduling or result in significantly greater CWP or IWP values as compared with the ISSCADA-plant feedback method was not realized in either year of this study. Therefore, the question arises as to the necessity of the TDR sensors. Having a redundant feedback system in place for automated site-specific irrigation management is prudent (McCarthy et al., 2014) and has been shown to have value in other applications of the ISSCADAhybrid method (Stone et al., 2019; Vories et al., 2019). Reducing the maximum SWD threshold from $50 \%$ in 2018 to $35 \%$ in 2019 resulted in maintaining two of the three ISSCADA-hybrid treatment plots (at the $\mathrm{I}_{100}$ level) at SWD levels below $35 \%$.

Our third objective, to consider the efficacy of the iCWSI thresholds that we calculated from the results of others, was not fully attained, but there is some indication that those thresholds should be adjusted to smaller values for our region. Increasing the cumulative irrigation amounts in the ISSCADA-plant feedback treatment plots and ensuring full irrigation in the ISSCADA-hybrid treatment plots would require adjustment to the range of each of the three tiers of iCWSI thresholds. An additional measure to possibly improve irrigation scheduling for the ISSCADA-hybrid method would be to add weights to the soil water readings at each layer, giving greater weight to layers in the most effective part of the rooting depth. This adjustment to the iCWSI thresholds, along with the maximum SWD threshold set at $35 \%$, would require additional testing.

\section{Conclusions}

This two-year study compared potato responses to three irrigation treatment levels and three irrigation scheduling methods. Potato responses to the three irrigation scheduling methods, including manual-control irrigation scheduling based on weekly NP readings and the ISSCADA-plant feedback and ISSCADA-hybrid irrigation scheduling methods, demonstrated that in a drier year, the mean cumulative irrigation amounts for both ISSCADA irrigation scheduling methods at the $\mathrm{I}_{100}$ level were $9 \%$ less than those for the manual-control method. This led to soil water deficit in the root zone and a significant reduction in overall tuber yields, CWP, and IWP. In the second year of the study, a relatively wet year, the maximum SWD threshold for the ISSCADA- 
hybrid method was reduced to $35 \%$ from $50 \%$ in 2018 . Potato responses during the wet year to all three irrigation scheduling methods were similar for tuber yield and CWP. Cumulative irrigation savings for the ISSCADA irrigation scheduling methods were at least $16 \%$ of the cumulative irrigation amounts applied using the manual-control method at the $\mathrm{I}_{100}$ level. Moreover, IWP was significantly greater for the ISSCADA-plant feedback method as compared with the manual-control method. Maintaining the maximum SWD level at $35 \%$ and decreasing the maximum and medium iCWSI threshold levels could enable the ISSCADA system to adjust to variable climatic seasons. Further studies are needed to investigate the consistency of the ISSCADA-hybrid method with these threshold changes for potato production. In both years, potato responses to the three irrigation levels, i.e., $100 \%, 80 \%$ and $60 \%$ replenishment of soil water depletion to field capacity, demonstrated that mild deficit irrigation at the $\mathrm{I}_{80}$ level resulted in tuber yields similar to those at the $\mathrm{I}_{100}$ treatment level. However, deficit irrigation at the $\mathrm{I}_{60}$ level resulted in significantly less yield compared with the $\mathrm{I}_{100}$ treatment level. Irrigation treatment level had no significant effect on CWP.

\section{ACKNOWLEDGEMENTS}

This article is based on work that is supported in part by the USDA National Institute of Food and Agriculture under Award No. 2016-67021-24420, the National Institute of Agricultural Sciences and the Rural Development Administration of South Korea through the RDA-ARS Virtual Laboratory (RAVL) program coordinated by OIRP (PJ 012748012019), and by the Ogallala Aquifer Program, a consortium between the USDA-ARS, Kansas State University, Texas AgriLife Extension Service and Research, Texas Tech University, and West Texas A\&M University. The work reported in this article was also accomplished as part of a Cooperative Research and Development agreement between the USDA-ARS and Valmont Industries, Inc., Valley, Nebraska (Agreement No. 58-3K95-0-1455-M).

\section{REFERENCES}

Adams, S. S., \& Stevenson, W. R. (1990). Water management, disease development, and potato production. American Potato J., 67(1), 3-11. https://doi.org/10.1007/BF02986908

Ahmadi, S. H., Agharezaee, M., Kamgar-Haghighi, A. A., \& Sepaskhah, A. R. (2014). Effects of dynamic and static deficit and partial root zone drying irrigation strategies on yield, tuber sizes distribution, and water productivity of two field-grown potato cultivars. Agric. Water Mgmt., 134, 126-136. https://doi.org/10.1016/j.agwat.2013.11.015

Ahmadi, S. H., Andersen, M. N., Plauborg, F., Poulsen, R. T., Jensen, C. R., Sepaskhah, A. R., \& Hansen, S. (2010). Effects of irrigation strategies and soils on field grown potatoes: Yield and water productivity. Agric. Water Mgmt., 97(11), 1923-1930. https://doi.org/10.1016/j.agwat.2010.07.007

Allen, R. G., Pereira, L. S., Raes, D., \& Smith, M. (1998). Crop evapotranspiration: Guidelines for computing crop water requirements. FAO Irrigation and Drainage Paper No. 56. Rome, Italy: United Nations FAO.
Allen, R. G., Walter, I. A., Elliott, R., Howell, T. A., Itenfisu, D., \& Jensen, M. E. (2005). The ASCE standardized reference evapotranspiration equation. Reston, VA: ASCE Task Committee on Standardization of Reference Evapotranspiration. https://doi.org/10.1061/9780784408056

Andrade, M. A., O’Shaughnessy, S. A., \& Evett, S. R. (2015). Advances in irrigation management tools: The development of ARSmartPivot. ASABE Paper No. 152170793. St. Joseph, MI: ASABE. https://doi.org/10.13031/irrig.20152170793

Andrade, M. A., O’Shaughnessy, S. A., \& Evett, S. R. (2016). A GIS-based decision support tool for center-pivot irrigation systems. ASABE Paper No. 162461449. St. Joseph, MI: ASABE. https://doi.org/10.13031/aim.20162461449

Andrade, M. A., O'Shaughnessy, S. A., \& Evett, S. R. (2017). ARSPivot, a sensor-based decision support tool for the integrated irrigation management of VRI center-pivot systems. Proc. Central Plains Irrigation Conf. Retrieved from https://www.ksre.k-state.edu/irrigate/oow/p17/Andrade17.pdf

Box, J. E., Sletten, W. H., Kyle, J. H., \& Pope, A. (1963). Effects of soil moisture, temperature, and fertility on yield and quality of irrigated potatoes in the Southern Plains. Agron. J., 55(5), 492494. https://doi.org/10.2134/agronj1963.00021962005500050025x

Chávez, J. L., \& Evett. S., R. (2012). Using soil water sensors to improve irrigation management. Proc. 24th Annual Central Plains Irrigation Conf. (pp. 187-202). Retrieved from https://www.ksre.k-state.edu/irrigate/oow/p12/Chavez12.pdf

El-Abedin, T. K., Mattar, M. A., Alazba, A. A., \& Al-Ghobari, H. M. (2017). Comparative effects of two water-saving irrigation techniques on soil water status, yield, and water use efficiency in potato. Scientia Hort., 225, 525-532. https://doi.org/10.1016/j.scienta.2017.07.044

Enciso, J., Black, M., \& Matocha, M. (2009). Crop profile for potatoes in Texas. In National IPM data base. Retrieved from https://ipmdata.ipmcenters.org/documents/cropprofiles/TXpotat oes2009.pdf

Evett, S. R. (2008). Neutron moisture meters. In S. Evett, L. K. Heng, P. Moutonnet, \& M. L. Nguyen (Eds.), Field estimation of soil water content: A practical guide to methods, instrumentation, and sensor technology (pp. 39-54). IAEA-TCS30. Vienna, Austria: International Atomic Energy Agency. Retrieved from heep://wwwpub.iaea.org/mtch/publications/PubDetails.asp?Pubid-7801

Evett, S. R., \& Parkin, G. W. (2005). Advances in soil water content sensing: The continuing maturation of technology and theory. Vadose Zone J., 4(4), 986-991. https://doi.org/10.2136/vzj2005.0099

Evett, S. R., O’Shaughnessy, S. A., \& Peters, R. T. (2014). Irrigation scheduling and supervisory control and data acquisition system for moving and static irrigation systems. U.S. Patent No. 8,924,031.

Evett, S. R., Stone, K. C., Schwartz, R. C., O’Shaughnessy, S. A., Colaizzi, P. D., Anderson, S. K., \& Anderson, D. J. (2019). Resolving discrepancies between laboratory-determined field capacity values and field water content observations: Implications for irrigation management. Irrig. Sci., 37(6), 751759. https://doi.org/10.1007/s00271-019-00644-4

Gerhards, M., Rock, G., Schlerf, M., \& Udelhoven, T. (2016). Water stress detection in potato plants using leaf temperature, emissivity, and reflectance. Intl. J. Appl. Earth Obs. Geoinfo., 53, 27-39. https://doi.org/10.1016/j.jag.2016.08.004

Heng, L. K., Hsiao, T., Evett, S. R., Howell, T. A., \& Steduto, P. (2009). Validating the FAO AquaCrop model for irrigated and water-deficient field maize. Agron. J., 101(3), 488-498. https://doi.org/10.2134/agronj2008.0029xs 
Ierna, A., \& Mauromicale, G. (2018). Potato growth, yield and, water productivity response to different irrigation and fertilization regimes. Agric. Water Mgmt., 201, 21-26. https://doi.org/10.1016/j.agwat.2018.01.008

Jackson, R. D., Idso, S. B., Reginato, R. J., \& Pinter Jr., P. J. (1981). Canopy temperature as a crop water stress indicator. Water Resour. Res., 17(4), 1133-1138. https://doi.org/10.1029/WR017i004p01133

Karam, F., Amacha, N., Fahed, S., El Asmar, T., \& Domínguez, A. (2014). Response of potato to full and deficit irrigation under semiarid climate: Agronomic and economic implications. Agric. Water Mgmt., 142, 144-151. https://doi.org/10.1016/j.agwat.2014.05.007

Kashyap, P. S., \& Panda, R. K. (2003). Effect of irrigation scheduling on potato crop parameters under water stressed conditions. Agric. Water Mgmt., 59(1), 49-66. https://doi.org/10.1016/S0378-3774(02)00110-5

Kifle, M., \& Gebretsadikan, T. G. (2016). Yield and water use efficiency of furrow irrigated potato under regulated deficit irrigation, Atsibi-Wemberta, North Ethiopia. Agric. Water Mgmt., 170, 133-139. https://doi.org/10.1016/j.agwat.2016.01.003

King, B. A., Stark, J. C., \& Wall, R. W. (2006). Comparison of sitespecific and conventional uniform irrigation management for potatoes. Appl. Eng. Agric., 22(5), 677-688. https://doi.org/10.13031/2013.22000

McCarthy, A. C., Hancock, N. H., \& Raine, S. R. (2014). Simulation of irrigation control strategies for cotton using model predictive control within the VARIwise simulation framework. Comput. Electron. Agric., 101, 135-147. https://doi.org/10.1016/j.compag.2013.12.004

O’Brien, M. J., \& Rich, A. E. (1979). Potato diseases. Agric. Handbook No. 474. Washington, DC: USDA Agricultural Research Service. https://naldc.nal.usda.gov/download/CAT31007970/PDF

Olanya, O. M., Porter, G. A., Lambert, D. H., Lakin, R. P., \& Starr, G. C. (2010). The effects of supplemental irrigation and soil management on potato tuber diseases. Plant Pathol. J., 9(2), 6572. https://doi.org/10.3923/ppj.2010.65.72

O'Shaughnessy, S. A., Andrade, M. A., \& Evett, S. R. (2017). Using an integrated crop water stress index for irrigation scheduling of two corn hybrids in a semi-arid region. Irrig. Sci., 35(5), 451-467. https://doi.org/10.1007/s00271-017-0552-x

O’Shaughnessy, S. A., Andrade, M. M., Stone, K. C., Vories, E. D., Sui, R., \& Evett, S. R. (2018). Adapting a VRI irrigation scheduling system for different climates. Proc. Irrigation Technical Conf. Retrieved from https://www.irrigation.org/IA/FileUploads/IA/Resources/Techni calPapers/2018/Adapting_SiteSpecific_Irrigation_OSHAUGHNESSY.pdf

O’Shaughnessy, S. A., Evett, S. R., \& Colaizzi, P. D. (2015). Dynamic prescription maps for site-specific variable-rate irrigation of cotton. Agric. Water Mgmt., 159, 123-138. https://doi.org/10.1016/j.agwat.2015.06.001

O’Shaughnessy, S. A., Urrego, Y. F., Evett, S. R., Colaizzi, P. D., \& Howell, T. A. (2013). Assessing application uniformity of a variable-rate irrigation system in a windy location. Appl. Eng. Agric., 29(4), 497-510.

https://doi.org/http://dx.doi.org/10.13031/aea.29.9931

Peters, R. T., \& Evett, S. R. (2004). Modeling diurnal canopy temperature dynamics using one-time-of-day measurements and a reference temperature curve. Agron. J., 96(6), 1553-1561. https://doi.org/10.2134/agronj2004.1553
Ramírez, D. A., Yactayo, W., Rens, L. R., Rolando, J. L., Palacios, S., De Mendiburu, F., ... Quiroz, R. (2016). Defining biological thresholds associated to plant water status for monitoring water restriction effects: Stomatal conductance and photosynthesis recovery as key indicators in potato. Agric. Water Mgmt., 177, 369-378. https://doi.org/10.1016/j.agwat.2016.08.028

Rens, L. R., Zotarelli, L., Cantliffe, D. J., Stoffella, P. J., Gergela, D., \& Burhans, D. (2015). Rate and timing of nitrogen fertilizer application on potato FL186: Part II. Marketable yield and tuber quality. Field Crops Res., 183, 267-275. https://doi.org/10.1016/j.fcr.2015.08.008

Robins, J. S., \& Domingo, C. E. (1956). Potato yield and tuber shape as affected by severe soil-moisture deficits and plant spacing. Agron. J., 48(11), 488-492. https://doi.org/10.2134/agronj1956.00021962004800110003x

Rud, R., Cohen, Y., Alchanatis, V., Levi, A., Brikman, R., Shenderey, C., ... Nigon, T. (2014). Crop water stress index derived from multi-year ground and aerial thermal images as an indicator of potato water status. Prec. Agric., 15(3), 273-289. https://doi.org/10.1007/s11119-014-9351-z

Ruf Jr., R. H. (1964). The influence of temperature and moisture stress on tuber malformation and respiration. American Potato J., 41(11), 377-381. https://doi.org/10.1007/BF02862848

Sanders, D. C., Nylund, R. E., Quisumbing, E. C., \& Shetty, K. V. (1972). The influence of mist irrigation on the potato: IV. Tuber quality factors. American Potato J., 49(7), 243-254. https://doi.org/10.1007/BF02861767

Schwartz, R. C., Evett, S. R., \& Unger, P. W. (2003). Soil hydraulic properties of cropland compared with re-established and native grassland. Geoderma, 116(1), 47-60. https://doi.org/10.1016/S0016-7061(03)00093-4

Schwartz, R. C., Evett, S. R., Anderson, S. K., \& Anderson, D. J. (2016). Evaluation of a direct-coupled time-domain reflectometry for determination of soil water content and bulk electrical conductivity. Vadose Zone J., 15(1), 2016. https://doi.org/10.2136/vzj2015.08.0115

Shae, J. B., Steele, D., \& Gregor, B. (1999). Irrigation scheduling methods for potatoes in the northern Great Plains. Trans. ASAE, 42(2), 351-360. https://doi.org/10.13031/2013.13366

Stone, K., Bauer, P., O'Shaughnessy, S., Andrade, M., \& Evett, S... (2019). A variable-rate irrigation decision support system for corn in the U.S. eastern coastal plain. In J. V. Stafford (Ed.), Precision agriculture' 19 (pp. 673-679). Wageningen, The Netherlands: Wageningen Academic. https://doi.org/10.3920/978-90-8686-888-9_83

Tolk, J. A., \& Evett, S. R. (2012). Lower limits of crop water use in three soil textural classes. SSSA J., 76(2), 607-616. https://doi.org/10.2136/sssaj2011.0248

Unger, P. W. (1996). Soil bulk density, penetration resistance, and hydraulic conductivity under controlled traffic conditions. Soil Tillage Res., 37(1), 67-75. https://doi.org/10.1016/01671987(95)00508-0

Unlu, M., Kanber, R., Senyigit, U., Onaran, H., \& Diker, K. (2006). Trickle and sprinkler irrigation of potato (Solanum tuberosum L.) in the Middle Anatolian region in Turkey. Agric. Water Mgmt., 79(1), 43-71. https://doi.org/10.1016/j.agwat.2005.02.004

USDA-NRCS. (1995). SSURGO soil survey geographic data base. Misc. Pub. 1527. Washington, DC: USDA-NRCS.

USDA-NRCS. (2020). Web soil survey. Washington, DC: USDANRCS. Retrieved from http://websoilsurvey.nrcs.usda.gov/

Van Loon, C. D. (1981). The effect of water stress on potato growth, development, and yield. American Potato J., 58(1), 5169. https://doi.org/10.1007/BF02855380 
Vories, E., O’Shaughnessy, S., \& Andrade, M. (2019). Comparison of precision and conventional irrigation management of cotton. In J. V. Stafford (Ed.), Precision agriculture ' 19 (pp. 695-702). Wageningen, The Netherlands: Wageningen Academic. https://doi.org/10.3920/978-90-8686-888-9 86

Wolfe, D. W., Fereres, E., \& Voss, R. E. (1983). Growth and yield response of two potato cultivars to various levels of applied water. Irrig. Sci., 3(4), 211-222.

https://doi.org/10.1007/BF00272837
Yost, J. L., Huang, J., \& Hartemink, A. E. (2019). Spatial-temporal analysis of soil water storage and deep drainage under irrigated potatoes in the Central Sands of Wisconsin, USA. Agric. Water Mgmt., 217, 226-235.

https://doi.org/10.1016/j.agwat.2019.02.045 